\title{
Unequal Impact of Conditional Conservatism on Components Accruals: Evidence from French Capital Market
}

\author{
Sihem Hmani ${ }^{1}$ \\ ${ }^{1}$ Department of Accounting-Finance, Institut Supérieur de Comptabilité et d'Administration des Entreprises, \\ University of Manouba, Tunisia \\ Correspondence: Sihem Hmani, Department of Accounting-Finance, Institut Supérieur de Comptabilité et \\ d'Administration des Entreprises, University of Manouba, Tunisia. E-mail: Sihem.hmani@iscae.uma.tn
}

Received: April 22, 2019

Accepted: May 19, 2019

Online Published: May 24, 2019

doi:10.5430/afr.v8n2p245

URL: https://doi.org/10.5430/afr.v8n2p245

\begin{abstract}
Applied to the French context, this study examines the unequal impact of conditional conservatism on accrual components. The study's sample is an unbalanced panel of 331 French companies listed on Euronext Paris during the period time going from 2000 till 2015. First, this work aims at attributing empirical evidence to conditional conservatism using Basu (1997) and Khan and Watts (2009) models to detect this accounting practice. Then, it analyses differential implications of conditional conservatism on accrual components.
\end{abstract}

Actually, French companies are known to be conservative firms as they implement conditional conservatism through an accrual component of earning, two accruals drivers (Revenue and receivables) and the non-discretionary accrual. According to Richardson, Sloan, Soliman \& Tuna (2005), the working capital component is the preferred tool, among accrual components, for the transmission of conditional conservatism.

Keywords: conditional conservatism, Basu model, C-Score measure, accruals drivers, discretionary accruals, non-discretionary accruals, accrual reliability

\section{Introduction}

The recent penchant for conservative accounting practices was revealed to the public through the Coca Cola affair. In September 2015, the American tax department imposed a tax adjustment of more than $\$ 3.3$ billion on the multinational, following five-year investigation. The contentious period covers Coca-Cola's tax returns from 2007 to 2009. During these three years, the American multinational downgraded the recognition of part of its income: the royalties perceived by Coca Cola abroad concerning its licenses and other patents related to the production, the distribution, the sale and the marketing of its products. Since that time, it is considered a champion of conservatism.

Accounting's conservatism is a convention that is found in any accounting system at different levels. Conservatism is a term derived from the Anglo-Saxon accounting model; it has no equivalent in the European model where it is replaced by the prudence principle. However, these two concepts are equivalent. The definition of conservatism differs whether you are an accounting standard setter or an academic researcher. The first is implicitly defined by the prudence concept by taking into account a certain degree of precaution in the exercise of judgments required to prepare estimates under conditions of uncertainty. The academician, precisely Sudipta Basu the founder of conservatism, states that "Conservatism is the accountant tendency to require a higher degree of verification to recognize good news as gains than to recognize bad news as losses” (Basu, p.7; 1997). As a result, earnings reflect bad news more quickly than good news.

According to the literature, two types of accounting conservatism are identified: the conditional conservatism linked to the news and the unconditional conservatism inherent in the choice of accounting methods. Both types of conservatism lead to an asymmetry of recognition of losses and gains and a systematic undervaluation of assets (liabilities).

Basu (1997) was the first to measure conservatism through an Earning/return relation. Called the Differential Timeliness (DT) model, stock returns are used as a measure of news (Note 1). Positive and negative returns represent, respectively, good and bad news and the differential response to bad news versus good news is the indicator of conditional conservatism (the Basu coefficient). Basu model is supported by many authors (Pope \& Walker, 1999; Ball, Kothari \& Robin, 2000, 2008; Givoly \& Hayn, 2000; Sivakumar \& Waymire, 2003; Beekes, Pope \& Young, 
2004; Krishnan, 2005; Pae, Thornton \& Welker, 2005; Bushman \& Piotroski, 2006; Lobo \& Zhou, 2006; Ahmed \& Duellman, 2007; Roychowdhury \& Watts, 2007; Beatty, Weber and Yu, 2008; Lafond \& Roychowdhury, 2008; Lafond \& Watts, 2008; Zhang, 2008; and Hsu, O'Hanlon \& Peasnell Hsu, 2012). Nevertheless, Dietrich, Muller \& Riedl, 2007 and Patatoukas \& Thomas (2011) state that Basu coefficient can be positive even in the absence of conditional conservatism. In addition, Beatty (2007) indicates that the stock return is not a new proxy when there is an underpricing of securities. Moreover, Givoly, Hayn, \& Natarajan, (2007) suggest that Basu coefficient is sensitive to the degree of uniformity in the content of the news during the examined period, the types of events occurring in the period, and the firm's disclosure policies.

The major result of the Basu study (1997) is that conservatism affects the result and cash flows differently. The latter is produced on the basis of realization and are therefore not affected by conservatism. Since the result is the sum of accruals and cash flows, it is then the accruals that are the vector of transmission of conservatism (Basu, 1997; Pope \& Walker, 1999; Ball, and al., 2000). Produced from an Anglo-Saxon reflection, the accruals designate the revenues and expenses that did not give rise to any flows during the year. Originate in the commitment accounting, Healy (1985, p.89) was the first to define them as the set of "accounting adjustments to the cash-flows of the enterprise permitted by the standardization bodies..."

The differential implication of conservatism on accruals is currently the most popular research route in the accounting literature. Moreover, results reached are conclusive even if very few researches have investigated that topic. Thus, the main acknowledgement is that accruals are the ultimate transmission vector of conservatism (Tazawa, 2003; Moreira \& Pope, 2006; Pae, 2007; Luo, 2012). This major result is, however, nuanced as drivers of accruals, discretionary accruals and reliable accruals (financial accruals) are not used for asymmetrical recognition of gains and losses. In addition, some components of the accruals are more conservative than others, such as operating accruals and non-current operating accruals.

To date, no study has addressed the differential implications of conditional conservatism on accruals and their components on French companies. In that context, our work deals with conditional conservatism's consequences on accruals and their derivates applied to a representative panel of French companies. The main issues raised are to determine if French firm's practice conditional conservatism and in the case they do to establish clearly, how conditional conservatism affects accruals and their components in a different way?

This study is organized around four sections. A review of the literature and research hypotheses is exhaustively presented in the first part. Then, the methodology chosen and adopted is given and explained. The third section is devoted to the sample presentation. Finally, the empirical results are given and analyzed.

\section{An Overview of the Literature and Development of the Testing Hypothesis}

The evidence available in the literature (Note 2) shows that the impact of conservatism is reflected on accruals and cash flows that are not contemporaneously affected by conservatism because those are originated on a realization basis: the asymmetric effect of conservatism impacts earnings through accruals (short-term and long-term accruals). Moreira \& Pope (2006) and Dimitropoulos (2008) test empirically the relative timing of accrual measures and earnings components used as explanatory variables in accrual models (accrual drivers) regarding the impact of conservatism.

Accrual models are used in the detection of potential fraudulent activity and the quality of the published financial statements. They decompose total accruals between the non-discretionary component, which captures the impact of business conditions, and the discretionary component which reflects managerial choices. Non-discretionary accruals are estimated as a function of changes in sales and the level of property, plant and equipment (Jones, 1991; DeFond \& Jiambalvo, 1994) whose are originated on a realization basis (Note 3) and thus are not contemporaneously affected by conservatism, in contrast with total accruals. The most drivers commonly included in accrual models has revenue and cash received (Peasnell, Pope \& Young, 2000), change in sales (Jones, 1991), and expenses (Kang \& Sivaramakrishnan, 1995). For example, the expectation that a costumer's debt will not be receiving the accounting recognizes immediately such a loss (Bad News). On the contrary, a bad debt, already recorded as such, that is expected to be total or partly recovered shall not be recognized until the receipt is realized (Good News). Thus, the recognition of bad news is faster than the recognition of good news; hence the impact of conservatism accrual learnings is negative. When bad news is recognized, the accruals are affected (exp. provisions for bad debts) but the drivers are not (revenue, sales, change in sales or expenses). In the case of good news, neither accruals nor the drivers are expected to be affected. This example reflects the asymmetrical treatment of gains and losses behind the principle of conservatism. Losses (Bad News) must be recognized immediately after they become expected, while gains (Good News) will be recognized only when they become feasible. 
Using revenue, cash received, change in revenue and expenses as accrual drivers, Moreira \& Pope (2006) and Dimitropoulos (2008), conclude that the asymmetric impact of conservatism holds only for accrual measures not for the accrual drivers (Note 4). Following these authors, we hypothesized that accrual drivers are unaffected by conservatism (generated according to the realization basis) while accrual measures (total accruals) are expected to be asymmetrically affected by conservatism (bad news are recognized immediately after they become expected but the good news are recognized when they become realized). Thus we expect that accrual measures will be asymmetrically affected by conservatism. The following hypothesis is formed:

$\mathrm{H}_{1}$ : Conditional conservatism is expected to affect accrual measures, but not accrual drivers.

Conditional accounting conservatism reflected in earnings and accruals is consistent with Generally Accepted Accounting Principles replete with the asymmetric treatment of good news versus bad news: the recognition of unrealized good news is generally prohibited, but the recognition of unrealized bad news is permitted. Therefore, it is unclear whether management discretion over accruals (measured by discretionary accruals) increases or decreases the degree of conditional accounting conservatism (Pae, 2007; p. 682). The earnings management literature suggests that managers accelerate the recognition of good news (incentive remuneration hypothesis) and postpone or hide bad news when the recognition of bad news endangers the manager's mandate. Under these two assumptions, managerial discretion over accruals would decrease the level of conditional accounting conservatism. Nevertheless, managers advance the recognition of bad news and delay the recognition of good news to improve the efficiency of the debt contract (Ball Robin \& Sadka, 2005) and reduce litigation costs (Watts, 2003). Under these two hypotheses, managers will exercise their discretion on an accruals to improve the degree of conditional accounting conservatism.

Theoretical predictions contradict the contribution of discretionary accruals to conditional conservatism. Pae (2007) postulates discretionary accruals don't transmit conditional conservatism. Their results contradict this hypothesis by showing that managers exercise their discretion over accruals to accelerate the recognition of bad news rather than good news. On the other hand, Dimitropoulos (2008) has shown that discretionary accruals are positively affected by conservatism, but test the difference of good and bad news coefficients indicates that discretionary accruals recognize the good and the bad news at the same time. In view of theoretical predictions and empirical results, the hypothesis regarding the contribution discretionary accruals to conditional accounting conservatism reflected in earnings and accruals is stated in null form.

$\mathrm{H}_{2}$ : Discretionary accruals do not contribute to conditional conservatism.

Reliability is one of the four key qualitative characteristics of financial accounting information. It requires that the information should be accurate and true and fair. Richardson, Sloan, Soliman \& Tuna (2005) decompose total accruals into three different reliability components: current operating/Working capital accruals, non-current operating accruals and financial accruals. Table 1 summarizes reliability assessments by accrual category. 
Table 1. Summary of reliability assessments by accrual category

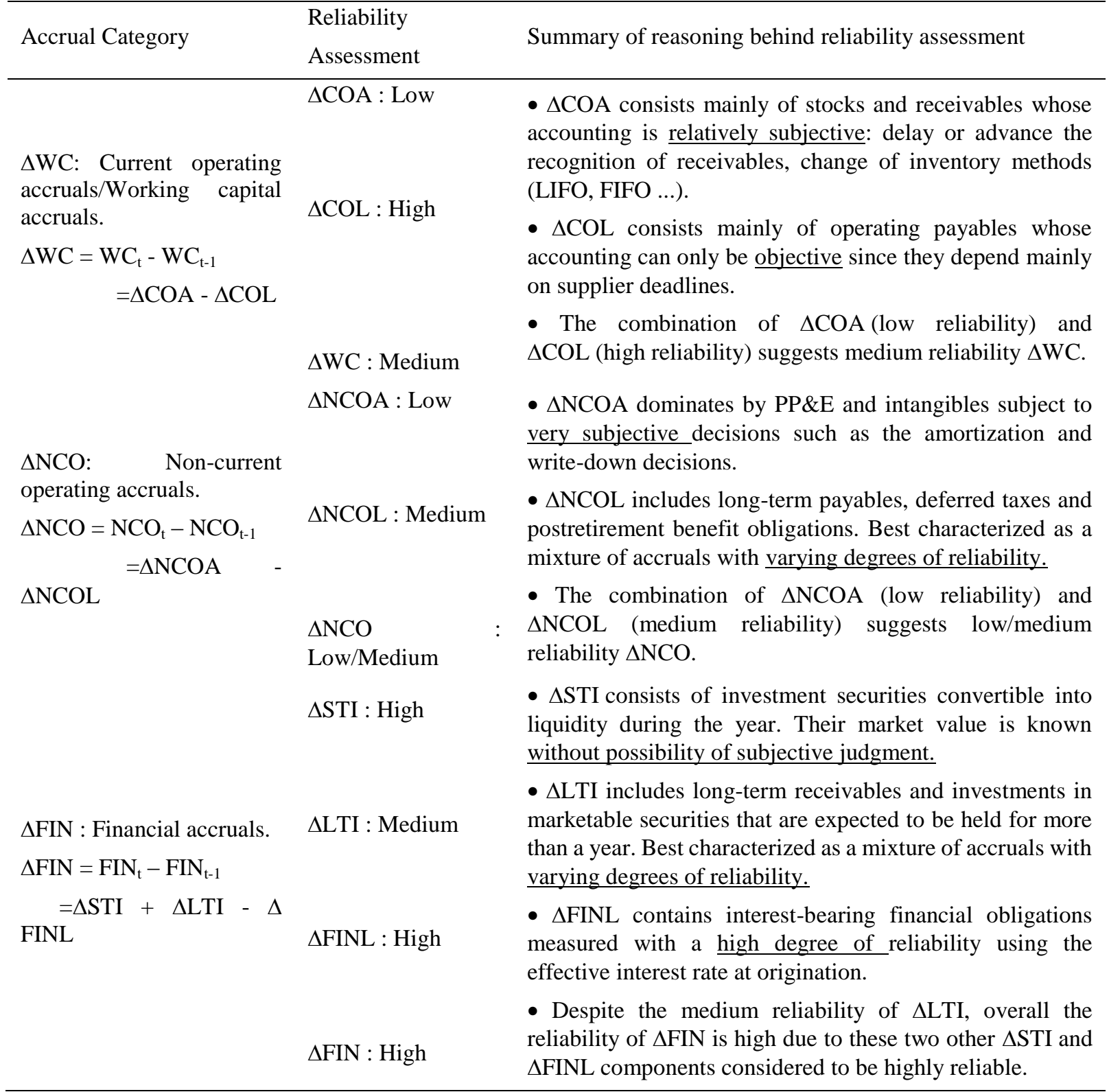

\section{Source: Inspired by Richardson, and al., (2005, p.448)}

Reliable accruals have sufficient objective evidence in reflecting good or bad news in earnings, whereas unreliable accruals need management discretion during the recognition of certain news (whether good or bad) into earnings. Consequently, the degree of conditional conservatism (timeliness of reflecting different news into gains or losses) is deemed to be different between these two accrual components (Luo, 2012). In fact, according to Richardson, and al., (2005), current operating accruals and non-current operating accruals have respective medium and low/medium reliability levels. Conversely, financial accruals are higher reliability. It remains to be seen between the two less reliable components which have the highest level of conservatism. Richardson, and al., (2005) recommend that non-current operating component reflect losses more quickly than gains than current operating component.

Luo (2012) does not specify a direction of the relationship between conservatism and the reliability of the accruals. In fact, in the presence of managerial incentives to bias financial reports upwards in an attempt to extract excess compensation, the degree of conditional conservatism may be expected to be lower for unreliable accruals than reliable ones. Therefore, standard setters, auditors and regulators impose on managers who bias reports may be larger than the benefits of discretion, so that managers adopt a higher degree of conditional 
conservatism for unreliable accruals than reliable ones. Further, managers may signal their financial reporting quality to the capital market by a strict application of the conditional conservatism especially to unreliable accruals.

Using a sample of 11.983 firm-year observations from 1990 to 2007, Luo (2012) find that unreliable accruals reflect losses relative to gains on a timelier basis than reliable accruals, suggesting that managers are more likely to conform to conservative reporting convention when they report unreliable accruals than less reliable accruals. Li \& Zhang (2015) provide evidence that, on average, reliable accrual component exhibits greater asymmetric timeliness than less reliable accrual component. Further, asymmetric timeliness do not seem to be reflected in different ways between non-current operating accruals and working capital accruals. These conflicting results lead to formulating hypothesis in a non-directional manner:

$\mathrm{H}_{3}$ : Unreliable accruals reflect losses relative to gains on a more or less timely basis compared to reliable accruals.

\section{Empirical Model and Variable Measurement}

\subsection{Measurement of Conditional Conservatism}

To test the unequal impact of conditional conservatism on components accruals, it is necessary to ensure the existence of this accounting practice. Two conditional conservatisms measures are used: Basu coefficient (Basu, 1997) and C-Score measure (Khan \& Watts, 2009).

\subsubsection{Basu Coefficient (Basu, 1997)}

Basu (1997) being the first to measure conservatism through an Earning/return relation. Called the Differential Timeliness (DT) model, stock returns are used as a measure of news (Note 5). Positive and negative returns represent good and bad news, respectively, and the differential response to bad news versus good news is the indicator of conditional conservatism (the Basu coefficient).

Basu (1997) specifies the following reverse (Note 6) annual regression:

$$
\frac{x_{i t}}{P_{i t-1}}=\alpha_{0}+\alpha_{1} D_{i t}+\beta_{0} R_{i t}+\beta_{1} R_{i t} \times D R_{i t}+\varepsilon_{\text {it }}
$$

$\mathrm{X}_{\mathrm{i}}$ : Earnings per share for firm $\mathrm{i}$ in fiscal year $\mathrm{t}$,

$\mathrm{P}_{\mathrm{it}-1}$ : Price per share at the beginning of the fiscal year,

$\mathrm{R}_{\mathrm{i}}=\left(\mathrm{P}_{\mathrm{it}}-\mathrm{P}_{\mathrm{it}-1}\right) / \mathrm{P}_{\mathrm{it}-1}$ : Return on firm i from 9 months before fiscal year-end $\mathrm{t}$ to 3 months after fiscal year-end $\mathrm{t}$ (Note 7),

$\mathrm{DR}_{\mathrm{it}}$ : Dummy variable $=1$ if $\mathrm{R}_{\mathrm{it}}<0,=0$ otherwise.

Stock return is used as measure of news: Negative and positive unexpected annual stock returns proxy respectively bad news and good news. $\beta 0$, the slope coefficient on returns, reflects the sensitivity of earnings to positive returns. $\beta_{1}$ measures the incremental timeliness of earnings, loss recognition. Conditional conservatism implies $\beta_{1}>0$. Then, coefficient $\beta_{1}$ indicates whether or not conservatism exists. It isn't a measure of the overall level of conditional conservatism $(\mathrm{Xi}, 2015)$. $\left(\beta_{0}+\beta_{1}\right)$ take the sensitivity of earnings to negative returns.

\subsubsection{C-Score Measure (Khan \& Watts, 2009)}

Khan \& Watts (2009) developed a firm-year measure of accounting conservatism based on Basu's (1997) notion of asymmetric timeliness and both empirical and theoretical evidence that firm size, market-to-book ratio and leverage generate cross-sectional variations in accounting conservatism. Khan \& Watts (2009) specify both, the timeliness of good news (G-Score) each year and the incremental timeliness of bad news (C-Score) each year, which are linear functions of firm-specific characteristics each year:

$$
\begin{gathered}
\beta_{0 \mathrm{t}}=\mathrm{G}-\text { Score }_{\text {it }}=\mu_{1}+\mu_{2} \text { Size }_{\mathrm{it}}+\mu_{3} \mathrm{M} / \mathrm{B}_{\mathrm{it}}+\mu_{4} \operatorname{Lev}_{\mathrm{it}} \\
\beta_{1 \mathrm{t}}=\mathrm{C}-\text { Score }_{\text {it }}=\varphi_{1}+\varphi_{2} \operatorname{Size}_{i \mathrm{t}}+\varphi_{3} \mathrm{M} / \mathrm{B}_{\mathrm{it}}+\varphi_{4} \operatorname{Lev}_{\mathrm{it}}
\end{gathered}
$$

Size: the natural log of market value of equity;

M/B: the market-to-book ratio;

Lev: the leverage of the firm.

Equation (4) results of substitution of equations (2) and (3) into (1). 


$$
\begin{aligned}
& \frac{X_{i t}}{P_{i t-1}}=\alpha_{0 t}+\alpha_{1 t} D_{i t}+R_{i t}\left(\mu_{1}+\mu_{2} \operatorname{Size}_{i t}+\mu_{3} M / B_{i t}+\mu_{4} \operatorname{Lev}_{i t}\right) \\
& +\mathrm{R}_{\mathrm{it}} \mathrm{DR}_{\mathrm{it}}\left(\varphi_{1}+\varphi_{2} \operatorname{Size}_{\mathrm{it}}+\varphi_{3} \mathrm{M} / \mathrm{B}_{\mathrm{it}}+\varphi_{4} \operatorname{Lev}_{\text {it }}\right)+\varepsilon_{\mathrm{it}}
\end{aligned}
$$

Additional terms are included in the regression model (4) to introduce interaction between returns and firm characteristics and also control for the firm characteristics separately (the main effects).

$$
\begin{gathered}
\frac{X_{i t}}{P_{i t-1}}=\alpha_{0 t}+\alpha_{1 t} D_{i t}+R_{i t}\left(\mu_{1}+\mu_{2} \operatorname{Size}_{i t}+\mu_{3} M / B_{i t}+\mu_{4} \operatorname{Lev}_{i t}\right) \\
+R_{i t} D_{i t}\left(\varphi_{1}+\varphi_{2} \operatorname{Size}_{i t}+\varphi_{3} M / B_{i t}+\varphi_{4} \operatorname{Lev}_{i t}\right)+\left(\delta_{1 \mathrm{t}} \operatorname{Size}_{i t}+\delta_{2 t} \frac{M}{B_{i t}}+\delta_{3 t} \operatorname{Lev}_{i t}\right. \\
\left.+\delta_{4} \mathrm{DR}_{\mathrm{it}} \operatorname{Size}_{i t}+\delta_{5} \mathrm{DR}_{\mathrm{it}} \frac{\mathrm{M}}{\mathrm{B}_{\mathrm{it}}}+\delta_{6} \mathrm{DR}_{\mathrm{it}} \operatorname{Lev}_{\mathrm{it}}\right)+\varepsilon
\end{gathered}
$$

The coefficients, $\widehat{\varphi}_{1}, \widehat{\varphi}_{2}, \widehat{\varphi}_{3}$ et $\widehat{\varphi}_{4}$, estimated from regression (5) are used to calculate the asymmetric timeliness C-Score.

$$
\mathrm{C}-\text { Score }_{i t}=\widehat{\varphi}_{1}+\widehat{\varphi}_{2} \operatorname{Size}_{i t}+\widehat{\varphi}_{3} \mathrm{M} / \mathrm{B}_{\mathrm{it}}+\widehat{\varphi}_{4} \operatorname{Lev}_{\mathrm{it}}
$$

3.1.3 Asymmetric Timeliness of Accruals Components

To test for the asymmetric impact of conservative accounting over earnings components and accruals (respectively total, drivers, discretionary, non-discretionary reliable and unreliable accruals), an adjusted version of Basu model is adopted. Therefore $\mathrm{X}$ it, earnings before the extraordinary item in the left-hand side in Basu's equation, is replaced with the previous accruals components

$$
\frac{Y_{i t}}{P_{i t-1}}=\alpha_{0}+\alpha_{1} D R_{i t}+\beta_{0} R_{i t}+\beta_{1} R_{i t} \times D R_{i t}+\varepsilon_{i t}
$$

$\mathrm{Y}_{\mathrm{it}}$ is, one at a time, each of earnings and accruals components,

$\mathrm{P}_{\mathrm{it}-1}$ : Price per share at the beginning of the fiscal year,

$\mathrm{R}_{\mathrm{it}}=($ Pit - Pit-1)/Pit-1: Return on firm i from 9 months before fiscal year-end $\mathrm{t}$ to three months after fiscal year-end $\mathrm{t}$,

$\mathrm{DR}_{\mathrm{it}}$ : Dummy variable $=1$ if $\mathrm{R}_{\mathrm{it}}<0,=0$ otherwise.

The variable $\mathrm{Y}$ is one at a time, the components used as accrual drivers in some of the most common models (change in revenue, revenue, cash received and level of property, plant and equipment), total accruals (Balance sheet approach), discretionary accruals, non-discretionary accruals, earnings before extraordinary items and Cash flow from operations.

To estimate non-discretionary accruals and discretionary accruals, Jones model (1991), modified Jones model (Dechow, Sloan \& Sweeney, 1995), Forward-looking model (Dechow, Richardson \& Tuna, 2003) Performance-matched model (Kothari, Sabino \& Zach, 2005) are used. The four models will be estimated in cross-section because it: generates and uses more observations, increases the validity of the parameter estimations, controls for the effect of non-stationarity (the time series model cannot) and finally increases the power of tests that examine time-series behavior in discretionary accruals. Despite numerous criticisms of the Jones model (1991) and modified Jones model (Dechow, and al., 1995), they are used to estimate non-discretionary accrual and discretionary accruals. Indeed, Pae (2007), whose approach adopted here, has proved that her results are insensitive to the ten models of measurement of discretionary accruals that he adopted. These two models are complemented by the Forward-looking model of Dechow, and al., (2003) and the Performance-matched model of Khotari, and al., (2005). The latter two models are considered by the accounting literature as the most effective.

Following to Richardson, and al., (2005), total accruals are decomposed into three categories as the equation (8): the change in net financial assets $(\Delta \mathrm{FIN})$, the change in non-cash working capital $(\Delta \mathrm{WC})$, and the change in non-current operating assets $(\triangle \mathrm{NCO})$. The change in net financial assets $(\triangle \mathrm{FIN})$ is considered to have high reliability, while the change in non-cash working capital $(\triangle \mathrm{WC})$ and the change in non-current operating assets $(\triangle \mathrm{NCO})$ are associated with relatively low reliability.

$$
\mathrm{TACC}=\Delta \mathrm{WC}+\Delta \mathrm{NCO}+\Delta \mathrm{FIN}
$$

In order to examine the asymmetric timeliness of unreliable and reliable accruals, Luo (2012) and Li \& Zang (2015) approaches are adopted. The three accrual components: the change in net financial assets $(\Delta \mathrm{FIN})$, the change in 
non-cash working capital $(\triangle \mathrm{WC})$ and the change in non-current operating assets $(\triangle \mathrm{NCO})$ replace earnings before the extraordinary item in the left-hand side of Basu model.

$$
\begin{aligned}
& \text { Reliable accruals : } \Delta \mathrm{FIN}_{\mathrm{i}, \mathrm{t}}=\alpha_{11}+\alpha_{21} \mathrm{DR}_{\mathrm{i}, \mathrm{t}}+\beta_{11} \mathrm{R}_{\mathrm{i}, \mathrm{t}}+\beta_{21} \mathrm{R}_{\mathrm{i}, \mathrm{t}} \mathrm{DR}_{\mathrm{i}, \mathrm{t}} \\
& \text { Unreliable accruals : } \Delta \mathrm{WC}_{\mathrm{i}, \mathrm{t}}=\alpha_{12}+\alpha_{22} \mathrm{DR}_{\mathrm{i}, \mathrm{t}}+\beta_{12} \mathrm{R}_{\mathrm{i}, \mathrm{t}}+\beta_{22} \mathrm{R}_{\mathrm{i}, \mathrm{t}} \mathrm{DR}_{\mathrm{i}, \mathrm{t}} \\
& \qquad \Delta \mathrm{NCO}_{\mathrm{i}, \mathrm{t}}=\alpha_{13}+\alpha_{23} \mathrm{DR}_{\mathrm{i}, \mathrm{t}}+\beta_{13} \mathrm{R}_{\mathrm{i}, \mathrm{t}}+\beta_{23} \mathrm{R}_{\mathrm{i}, \mathrm{t}} \mathrm{DR}_{\mathrm{i}, \mathrm{t}}
\end{aligned}
$$

After running the regression three times with different dependent variables $(\triangle \mathrm{FIN}, \Delta \mathrm{WC}, \Delta \mathrm{NCO})$, the asymmetric timeliness of unreliable accruals are compared with that of reliable accruals which represents as the benchmark. The index for the degree of asymmetric timeliness using the formula: Index $=\left(\beta_{1 \mathrm{x}}+\beta_{2 \mathrm{x}}\right) / \beta_{1 \mathrm{x}}$ is calculated. If the asymmetric timeliness is lower (higher) for unreliable accruals, the index would be smaller (larger), relative to those for the reliable accruals.

\subsection{Variables Definition and Measurement}

\begin{tabular}{|c|c|c|}
\hline Abbrev. & Variable & Measurement \\
\hline TACC & $\begin{array}{l}\text { Total accruals (Note 8) } \\
\text { (Richardson, and al., } \\
\text { 2005) }\end{array}$ & $\mathrm{TACC}=\Delta \mathrm{WC}+\Delta \mathrm{NCO}+\Delta \mathrm{FIN}$ \\
\hline$\Delta \mathrm{WC}$ & $\begin{array}{l}\text { Change in non-cash } \\
\text { working capital. }\end{array}$ & $\begin{array}{l}\Delta \mathrm{WC}=\mathrm{WC}_{\mathrm{t}}-\mathrm{WC}_{\mathrm{t}-1} \\
\Delta \mathrm{WC}=\Delta \mathrm{COA}-\Delta \mathrm{COL}=\left(\mathrm{COA}_{\mathrm{t}}-\mathrm{COA}_{\mathrm{t}-1}\right)-\left(\mathrm{COL}_{\mathrm{t}}-\mathrm{COL}_{\mathrm{t}-1}\right)\end{array}$ \\
\hline$\Delta \mathrm{COA}$ & $\begin{array}{l}\text { Change in current } \\
\text { operating assets, net of } \\
\text { cash and short-term } \\
\text { investments. } \\
\text { Measurement from World } \\
\text { Change in current }\end{array}$ & scope (WS) : COA = WS.TotalCurrentAssets - WS.CashAndSTInvestments \\
\hline$\Delta \mathrm{COL}$ & $\begin{array}{l}\text { operating liabilities, net } \\
\text { of short-term debt. } \\
\text { Measurement from } \\
\text { WS.STDebtAndCurPortLT }\end{array}$ & $\begin{array}{l}\text { COL }=\text { Current Liabilities }- \text { Debt in Current Liabilities } \\
\text { Worldscope } \\
\text { Debt }\end{array}$ \\
\hline$\Delta \mathrm{NCO}$ & $\begin{array}{l}\text { Change in non-current } \\
\text { operating assets. } \\
\text { Change in non-current }\end{array}$ & $\begin{array}{l}\Delta \mathrm{NCO}=\mathrm{NCO}_{\mathrm{t}}-\mathrm{NCO}_{\mathrm{t}-1}=\Delta \mathrm{NCOA}-\Delta \mathrm{NCOL}=\left(\mathrm{NCOA}_{\mathrm{t}}-\mathrm{NCOA}_{\mathrm{t}-1}\right)- \\
\left(\mathrm{NCOL}_{\mathrm{t}}-\mathrm{NCOL}_{\mathrm{t}-1}\right)\end{array}$ \\
\hline$\triangle \mathrm{NCOA}$ & $\begin{array}{l}\text { assets, net of long-term } \\
\text { non-equity investments } \\
\text { and advances. } \\
\text { Measurement from Wo } \\
\text { WS.OtherInvestments) }\end{array}$ & Idscope (WS) : NCOA= WS.TotalAssets - (WS.TotalCurrentAssets + \\
\hline \multirow[t]{2}{*}{$\triangle \mathrm{NCOL}$} & $\begin{array}{l}\text { Change in non-current } \\
\text { liabilities, net of } \\
\text { long-term debt. }\end{array}$ & $\begin{array}{l}\text { NCOL }=\text { Total Liabilities - Current Liabilities - Long-Term Debt } \\
\text { Richardson, and al., (2005) incorporate minority interests. It is the portion of } \\
\text { a subsidiary corporation's stock that is not owned by the parent corporation. } \\
\text { Also, minority interest is reported on the consolidated income statement as a } \\
\text { share of profit belonging to minority shareholders. Therefore, they have the } \\
\text { character of a non-financial liability of the parent company vis-à-vis its } \\
\text { subsidiaries. }\end{array}$ \\
\hline & $\begin{array}{l}\text { Measurement from World } \\
\text { NCOL =WS.TotalLiabi } \\
\text { WS.MinorityInterestBalSht }\end{array}$ & $\begin{array}{llll}\text { scope (WS) } & & \\
\text { lities } & - & \text { (WS.TotalCurrentLiabilities } & +\end{array}$ \\
\hline$\Delta$ FIN & $\begin{array}{l}\text { Change in net financial } \\
\text { assets. }\end{array}$ & $\begin{array}{l}\Delta \mathrm{FIN}=\mathrm{FIN}_{\mathrm{t}}-\mathrm{FIN}_{\mathrm{t}-1}=\Delta \mathrm{STI}+\Delta \mathrm{LTI}-\Delta \mathrm{FINL}=\left(\mathrm{STI}_{\mathrm{t}}-\mathrm{STI}_{\mathrm{t}-1}\right)+\left(\mathrm{LTI}_{\mathrm{t}}-\right. \\
\left.\mathrm{LTI}_{\mathrm{t}-1}\right)-\left(\mathrm{FINL}_{\mathrm{t}}-\mathrm{FINL}_{\mathrm{t}-1}\right)\end{array}$ \\
\hline$\Delta \mathrm{STI}$ & $\begin{array}{l}\text { Change in short-term } \\
\text { investments. } \\
\text { Measurement from World }\end{array}$ & $\begin{array}{l}\text { STI = Short-term investments } \\
\text { scope (WS) }: \text { STI }=\text { WS.STInvestments }\end{array}$ \\
\hline
\end{tabular}

Variables definition and measurement are summarized in Table 2:

Table 2. Variables definition and measurement 
Table 2 (continued): Variables definition and measurement

\begin{tabular}{|c|c|c|}
\hline Abbrev. & Variable & Measurement \\
\hline \multirow[t]{2}{*}{$\Delta \mathrm{LTI}$} & $\begin{array}{l}\text { Change in long-term } \\
\text { investments. }\end{array}$ & LTI $=$ Long-term investments \\
\hline & Measurement from Worl & dscope (WS) : LTI = WS.OtherInvestments \\
\hline \multirow[t]{2}{*}{$\Delta \mathrm{FINL}$} & $\begin{array}{l}\text { Change in financial } \\
\text { liabilities. }\end{array}$ & $\begin{array}{l}\text { FINL }=\text { short-term debt }+ \text { long-term debt }+ \text { preferred stock } \\
\text { Due to their hybrid characteristics: title/debt securities, preferred stocks } \\
\text { (Note 9) are an integral part of financial liabilities (Richardson and al., 2005). }\end{array}$ \\
\hline & Measurement from Worl & dscope $($ WS $):$ FINL = WS.TotalDebt + WS.PreferredStock \\
\hline \multirow{2}{*}{$\mathbf{R}$} & Stock returns. & $\begin{array}{l}R_{i t}=\left(P_{i t}-P_{i t-1}\right) / P_{i t-1}: \text { Return on firm i from } 9 \text { months before fiscal year-end } t \\
\text { to three months after fiscal year-end } t \text { (Note } 10) .\end{array}$ \\
\hline & & $\begin{array}{l}\mathrm{P}_{\mathrm{it}}: \text { Price per share at } 31 / 03 \text { after the end of fiscal year } \mathrm{t} \text { (closing price). } \\
\mathrm{P}_{\mathrm{it}-1}: \text { Price per share at } 01 / 04 \text { begins the end of fiscal year } t \text { (opening price). }\end{array}$ \\
\hline DR & Dummy variable. & $\mathrm{DR}_{\mathrm{it}}=1$ if $\mathrm{R}_{\mathrm{it}}<0$ and $\mathrm{DR}_{\mathrm{it}}=0$ if $\mathrm{R}_{\mathrm{it}} \geq 0$ \\
\hline \multirow[t]{2}{*}{ EBEI } & Earnings & EBEI: Earnings before extraordinary items. \\
\hline & Measurement from Worl & dscope (WS) : EBEI = TF.IncomeBefExtraItemsAndPfdDiv \\
\hline CFO & $\begin{array}{l}\text { Cash flow from } \\
\text { operations }\end{array}$ & CFO = EBEI - TACC (Indirect Method). \\
\hline \multirow[t]{2}{*}{ REV } & Revenue & Net sales. \\
\hline & Measurement from Worl & dscope (WS) : REV = WS.Sales \\
\hline$\triangle \mathbf{R E V}$ & Change in revenue & $\Delta$ Sales $=$ Sales $_{\mathrm{t}}-$ Sales $_{\mathrm{t}-1}$ \\
\hline \multirow[t]{2}{*}{ REC } & Receivables & Total receivables \\
\hline & Measurement from Worl & dscope $($ WS $):$ REC $=$ WS.TotalReceivables \\
\hline$\triangle \mathbf{R E C}$ & Change in receivables & $\Delta \mathrm{REC}=\mathrm{REC}_{\mathrm{t}}-\mathrm{REC}_{\mathrm{t}-1}$ \\
\hline \multirow[t]{2}{*}{ PPE } & $\begin{array}{l}\text { Level of property plant } \\
\text { and equipment }\end{array}$ & Total property plant and equipment. \\
\hline & Measurement from Worl & dscope (WS) : PPE = WS.TotalPropPlantEquipGross \\
\hline \multirow{3}{*}{ ROA } & Return On Assets & Operating income after depreciation deflated by average total assets \\
\hline & Measurement from Wo & Idscope (WS) : ROA = TF.ReturnOnAssets \\
\hline & Total Assets & Total assets. \\
\hline \multirow{2}{*}{ TA } & Calcul à partir de World & scope (WS) : TA = WS.TotalAssets \\
\hline & & $\Delta \mathrm{TA}=\mathrm{TA}_{\mathrm{t}}-\mathrm{TA}_{\mathrm{t}-1}$ \\
\hline$\Delta \mathbf{T A}$ & Average total assets & $\begin{array}{l}\text { All variables of discretionary accruals models are deflated by average total } \\
\text { assets. }\end{array}$ \\
\hline
\end{tabular}


Table 2 (continued): Variables definition and measurement

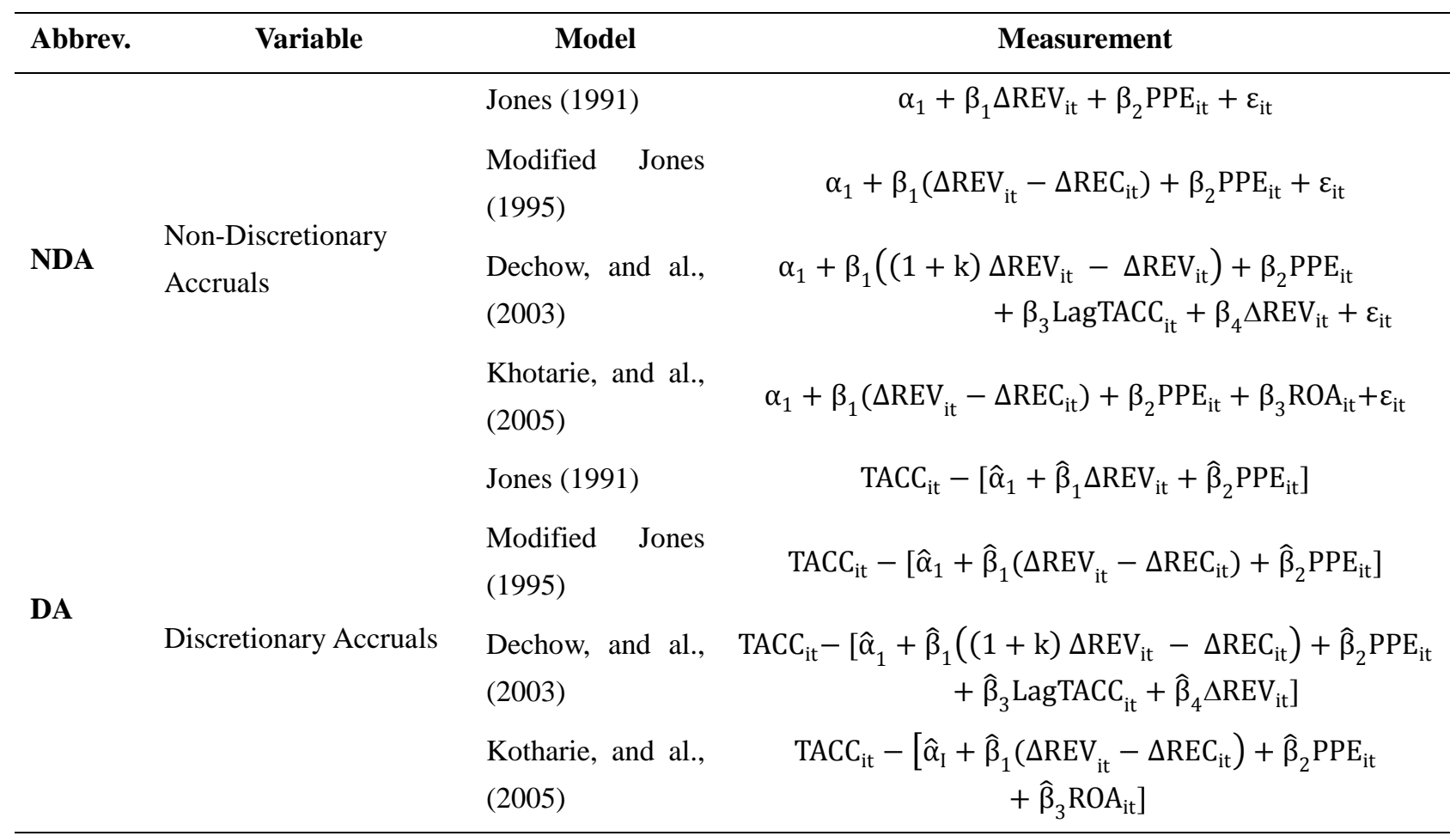

\section{Sample and Descriptive Statistics}

Stock exchange prices are collected directly from the Datastream database. For the accounting variables, the collection was made from the Thomson Worldscope database. The missing data were calculated directly from the business annular reports. To mitigate potential outlier problems, returns, earnings, operating cash flows, total accruals, accrual drivers, accrual components, discretionary and non discretionary accruals are winsorised at their respective first and 99th percentile values each year. The final sample consists of 5.245 firm-year observations over the fiscal year from 2000 to 2015 (Note 11).

Sample firms are divided into nine industries (ICB classification). Four industries dominate fairly the sample: industrials, consumer goods, technology and consumer services. The other five industries (Health care, Basic Materials, Oil and Gas, Utilities and Telecommunications) account for only $14 \%$ of the sample. $89 \%$ of the sampled companies are listed on the Eurolist Paris (28\% Eurolist A, 29\% Eurolist B and 43\% Eurolist C), 7\% on the Alternext Market and $4 \%$ of the Free Market.

Table 3 reports the descriptive statistics of key variables. Average and median cash flows from operations (CFO) are respectively negative and positive, suggesting that the distribution of the CFO positively skewed which is characteristic of the asymmetry of recognition of losses and profits inherent in CFO (Basu, 1997 and Pae, and al., 2005). Earnings before extraordinary items (EBEI) is slightly skewed to the left, consistent with the evidence in the literature that during the period firms have been reporting increasing losses. However, the mean and median are both positive. The standard deviation of EBEI is the smallest of all variables. This shows a piece of evidence of the income smoothing. For returns (R), the mean (median) and the minimum are $0.092(0.021)$ and -0.805 respectively, which are close to zero, and the maximum is 2.144 . This implies the upper-bias of returns.

Change in revenue $(\triangle \mathrm{REV})$ is asymmetrically distributed to the left then change in receivable ( $\triangle \mathrm{REC})$ distribution is symmetrical. The mean of total property, plant and equipment (PPE) is significantly higher than the median, indicating a dominance of firms with high tangible capital assets. Further, the dispersion of the PPE is higher due to the heterogeneity of the sample ( 9 industries). Indeed, a minimum value of 0.005 probably corresponds to a service firm with low tangible capital assets, while the maximum value of 16.461 is characteristic of a heavily immobilized industrial firm. 
Table 3. Descriptive Statistics of key variables

\begin{tabular}{llllll}
\hline Variable & Median & Mean & Standard Dev. & Min & Max \\
\hline R & 0.021 & 0.092 & 0.510 & -0.805 & 2.144 \\
DR & - & 0.47 & - & - & - \\
EBEI & 0.056 & 0.026 & 0.185 & -0.914 & 0.526 \\
CFO & 0.011 & -0.012 & 0.538 & -2.282 & 2.214 \\
TACC & 0.029 & 0.031 & 0.579 & -2.633 & 2.277 \\
$\Delta$ REV & 0.053 & 0.075 & 0.588 & -2.613 & 2.571 \\
$\Delta$ REC & 0.011 & 0.012 & 0.207 & -0.901 & 0.841 \\
PPE & 0.553 & 1.410 & 2.395 & 0.005 & 16.461 \\
NDA(J) & 0.030 & 0.036 & 0.073 & -0.233 & 0.303 \\
DA(J) & -0.011 & 0.006 & 0.210 & -0.632 & 0.920 \\
NDA(JM) & 0.033 & 0.034 & 0.050 & -0.158 & 0.212 \\
DA (JM) & -0.010 & 0.008 & 0.218 & -0.650 & 0.937 \\
NDA(K) & 0.026 & 0.026 & 0.063 & -0.250 & 0.232 \\
DA(K) & -0.006 & 0.016 & 0.211 & -0.574 & 0.942 \\
NDA(D) & 0.032 & 0.032 & 0.122 & -0.378 & 0.389 \\
DA(D) & -0.008 & 0.001 & 0.209 & -0.570 & 0.813 \\
$\Delta$ WC & 0.003 & -0.008 & 0.213 & -0.993 & 0.826 \\
$\Delta$ COA & 0.018 & 0.018 & 0.304 & -1.398 & 1.250 \\
$\Delta$ COL & 0.015 & 0.026 & 0.249 & -1.012 & 1.130 \\
$\Delta$ NCO & 0.013 & 0.029 & 0.270 & -1.172 & 1.237 \\
$\Delta$ NCOA & 0.011 & 0.037 & 0.270 & -0.881 & 1.441 \\
$\Delta$ NCOL & 0.001 & 0.009 & 0.116 & -0.881 & 1.441 \\
$\Delta$ FIN & 0.004 & 0.013 & 0.323 & -1.448 & 1.375 \\
$\Delta$ STI & 0 & 0.006 & 0.114 & -0.400 & 0.548 \\
$\Delta$ LTI & 0.000 & 0.002 & 0.054 & -0.247 & 0.304 \\
$\Delta$ FINL & 0.000 & 0.004 & 0.261 & -1.276 & 1.013 \\
\hline The dist & & 0.37 & \\
\hline
\end{tabular}

The distribution of the total accruals (TACC) is symmetric: the mean and median values are approximately equal. Median TACC is 2.9 percent average total assets (TA). Median Non-Discretionary Accruals (NDA) is positive whereas median Discretionary Accruals (DA) are negative and close to zero. The standard deviation of DA is more than that of the NDA. This implies that DA has a greater timeliness than NDA.

Mean TACC is $3.1 \%$ of average total assets (TA). The mean values of respectively non-current operating accruals $(\triangle \mathrm{NCO})$ and financial accruals $(\triangle \mathrm{FIN})$ are 0.029 and 0.013 ; both are positive while the mean value of current operating accruals $(\triangle \mathrm{WC})$ is negative $(-0.008)$. Moreover, most portion of the mean of TACC is long-term operating accruals; this is explained by the mean of component asset (0.037) far superior to the mean of component liability (0.009). Mean of $\triangle \mathrm{WC}$ are close to zero: Means and medians of the two components, asset and liability, are equivalents. Similarly, mean and median of $\Delta \mathrm{FIN}$ are close to zero because means and medians of the three components (asset and liability) are near to zero. Only the distribution of $\Delta \mathrm{WC}$ is positively skewed which is, probably, characteristic of the asymmetry of recognition of losses and profits. The standard deviation of $\Delta \mathrm{WC}$ appears to be lower than that of $\triangle \mathrm{FIN}$ and $\triangle \mathrm{NCO}$, suggesting for $\triangle \mathrm{WC}$ less variation in TACC, compared to $\triangle \mathrm{FIN}$ and $\triangle \mathrm{NCO}$.

Table 4 (Panel A) present Spearman (Note 12) correlations for total accruals, returns, cash flows from operations and accruals drivers. 
Table 4. Correlation matrix-Spearman correlations $(\mathrm{n}=5.245)$

Panel A: Spearman correlations for total accruals, returns, cash flows and accruals drivers

\begin{tabular}{llllllll}
\hline & $\mathbf{R}$ & $\mathbf{C F O}$ & TACC & EBEI & $\Delta \mathbf{R E V}$ & $\Delta \mathbf{R E C}$ & PPE \\
\hline $\mathbf{R}$ & & & & & & \\
$\mathbf{C F O}$ & $0.102^{* * *}$ & & & & & \\
& $(0.000)$ & & & & & \\
TACC & 0.012 & $-0.873^{* * *}$ & & & & \\
& $(0.358)$ & $(0.000)$ & & & & \\
EBEI & $0.325^{* * *}$ & $0.088^{* * *}$ & $0.254^{* * *}$ & & & \\
& $(0.000)$ & $(0.000)$ & $(0.000)$ & & & \\
$\Delta \mathbf{R E V}$ & $0.101^{* * *}$ & $-0.185^{* * *}$ & $0.325^{* * *}$ & $0.355^{* * *}$ & & \\
& $(0.000)$ & $(0.000)$ & $(0.000)$ & $(0.000)$ & & \\
$\Delta \mathbf{R E C}$ & $0.060^{* * *}$ & $-0.318^{* * *}$ & $0.405^{* * * *}$ & $0.233^{* * *}$ & $0.477^{* * *}$ & \\
& $(0.000)$ & $(0.000)$ & $(0.000)$ & $(0.000)$ & $(0.000)$ & \\
PPE & $0.132^{* * *}$ & $0.052^{* * *}$ & $-0.024^{*}$ & $0.137^{* * * *}$ & -0.001 & $-0.063^{* * *}$ & \\
& $(0.000)$ & $(0.000)$ & $(0.076)$ & $(0.000)$ & $(0.902)$ & $(0.000)$ \\
\hline
\end{tabular}

*** and * respectively significant at the $1 \%$ et $10 \%$ level.

Significant correlations appear in variables that are strongly related in accounting terms (EBEI, TACC, $\triangle \mathrm{REV}, \triangle \mathrm{REC}$ and PPE). In accordance with the literature, driver's accruals, ( $\triangle R E V, \triangle R E C$ and PPE) are significantly associated with TACC. Signs of correlations are respected: positive for $\triangle \mathrm{REV}$ and $\triangle \mathrm{REC}$ and negative for PPE. $\triangle \mathrm{REV}$ and $\triangle \mathrm{REC}$ are significantly and positively correlated. In fact, under the accrual basis of accounting, revenues and receivable are recorded when a company sells products on credit. Reversibility of accruals translates into a strong negative and significant correlation between CFO and TACC (Dechow, 1994). The correlation of R with the other variables (except EBEI and TACC) is fairly small and tends not to surpass 13.2 percent. Finally, R is significantly correlated with TACC $(0.325)$. It seems that accounting variable does have incremental information that can affect returns.

Panel B: Spearman correlations for total accruals, non discretionary accruals and discretionary accruals

\begin{tabular}{|c|c|c|c|c|c|c|c|c|c|}
\hline & TACC & NDA(J) & $\mathbf{D A}(\mathbf{J})$ & $\begin{array}{l}\text { NDA } \\
\text { (MJ) }\end{array}$ & DA(MJ) & NDA(K) & $\overline{\mathbf{D A}(\mathrm{K})}$ & NDA(D) & DA(D) \\
\hline \multicolumn{10}{|l|}{ TACC } \\
\hline $\operatorname{NDA}(J)$ & $\begin{array}{l}0.346 * * * \\
(0.000)\end{array}$ & & & & & & & & \\
\hline $\mathbf{D A}(\mathbf{J})$ & $\begin{array}{l}0.885^{* * *} \\
(0.358)\end{array}$ & $\begin{array}{l}-0.013 \\
(0.342)\end{array}$ & & & & & & & \\
\hline NDA (MJ) & $\begin{array}{l}0.207 * * * \\
(0.000)\end{array}$ & $\begin{array}{l}0.867 * * * \\
(0.000)\end{array}$ & $\begin{array}{l}-0.12 * * * \\
(0.000)\end{array}$ & & & & & & \\
\hline DA(MJ) & $\begin{array}{l}0.935^{* * * *} \\
(0.000)\end{array}$ & $\begin{array}{l}0.112 * * * \\
(0.000)\end{array}$ & $\begin{array}{l}0.972 * * * \\
(0.000)\end{array}$ & $\begin{array}{l}-0.05 * * * \\
(0.000)\end{array}$ & & & & & \\
\hline $\operatorname{NDA}(K)$ & $\begin{array}{l}0.300^{* * *} \\
(0.000)\end{array}$ & $\begin{array}{l}0.653^{* * *} \\
(0.000)\end{array}$ & $\begin{array}{l}0.037 * * * \\
(0.009)\end{array}$ & $\begin{array}{l}0.641 * * * \\
(0.000)\end{array}$ & $\begin{array}{l}0.109 * * * \\
(0.009)\end{array}$ & & & & \\
\hline $\mathbf{D A}(\mathbf{K})$ & $\begin{array}{l}0.912 * * * \\
(0.000)\end{array}$ & $\begin{array}{l}0.136^{* * *} \\
(0.000)\end{array}$ & $\begin{array}{l}0.903 * * * \\
(0.000)\end{array}$ & $\begin{array}{l}-0.006 \\
(0.627)\end{array}$ & $\begin{array}{l}0.951 * * * \\
(0.000)\end{array}$ & $\begin{array}{l}-0.011 \\
(0.437)\end{array}$ & & & \\
\hline $\operatorname{NDA}(D)$ & $\begin{array}{l}0.266^{* * *} \\
(0.000)\end{array}$ & $\begin{array}{l}0.416^{* * *} \\
(0.000)\end{array}$ & $\begin{array}{l}0.094 * * * \\
(0.000)\end{array}$ & $\begin{array}{l}0.226 * * * \\
(0.000)\end{array}$ & $\begin{array}{l}0.190 * * * \\
(0.000)\end{array}$ & $\begin{array}{l}0.266^{* * * *} \\
(0.000)\end{array}$ & $\begin{array}{l}0.173 * * * \\
(0.000)\end{array}$ & & \\
\hline $\mathbf{D A}(\mathbf{D})$ & $\begin{array}{l}0.722 * * * \\
(0.000)\end{array}$ & $\begin{array}{l}0.064 * * * \\
(0.000)\end{array}$ & $\begin{array}{l}0.772 * * * \\
(0.000)\end{array}$ & $\begin{array}{l}0.052 * * * \\
(0.000)\end{array}$ & $\begin{array}{l}0.738 * * * \\
(0.000)\end{array}$ & $\begin{array}{l}0.118 * * * \\
(0.000)\end{array}$ & $\begin{array}{l}0.732 * * * \\
(0.000)\end{array}$ & $\begin{array}{l}-0.36 * * * \\
(0.000)\end{array}$ & \\
\hline
\end{tabular}

*** Significant at the $1 \%$ level. 
All measures of DA are strongly and significantly related. Lesser than DA, the various measures of NDA are significantly correlated. The correlations from the NDA and DA, issue from Dechow, and al. (2003) model is less than those from other three models. It appears that this model, due to the improvements made to it, differs from other models. However, overall, the selected models are worth in their decompositions of the total accruals by discretionary and non-discretionary component.

Panel C: Spearman correlations for total and components accruals

\begin{tabular}{|c|c|c|c|c|c|c|}
\hline & TACC & CFO & EBEI & $\Delta \mathrm{WC}$ & $\triangle \mathrm{NCO}$ & $\Delta$ FIN \\
\hline \multicolumn{7}{|l|}{ TACC } \\
\hline CFO & $\begin{array}{l}-0.873 * * * \\
(0.000)\end{array}$ & & & & & \\
\hline EBEI & $\begin{array}{l}0.254 * * * \\
(0.000)\end{array}$ & $\begin{array}{l}0.088 * * * \\
(0.000)\end{array}$ & & & & \\
\hline$\Delta \mathbf{W C}$ & $\begin{array}{l}0.445^{* * *} \\
(0.000)\end{array}$ & $\begin{array}{l}-0.367 * * * \\
(0.000)\end{array}$ & $\begin{array}{l}01.78 * * * \\
(0.000)\end{array}$ & & & \\
\hline$\triangle \mathrm{NCO}$ & $\begin{array}{l}0.581 * * * \\
(0.000)\end{array}$ & $\begin{array}{l}-0.488^{* * *} \\
(0.000)\end{array}$ & $\begin{array}{l}0.215^{* * *} \\
(0.000)\end{array}$ & $\begin{array}{l}-0.000 \\
(0.998)\end{array}$ & & \\
\hline$\Delta \mathbf{F I N}$ & $\begin{array}{l}0.786^{* * *} \\
(0.000)\end{array}$ & $\begin{array}{l}-0.774 * * * \\
(0.000)\end{array}$ & $\begin{array}{l}0.112 * * * \\
(0.000)\end{array}$ & $\begin{array}{l}0.190 * * * \\
(0.000)\end{array}$ & $\begin{array}{l}0.308 * * * \\
(0.000)\end{array}$ & \\
\hline
\end{tabular}

*** Significant at the $1 \%$ level.

All correlation coefficients are significant at the $1 \%$ level except for coefficient of $\Delta \mathrm{WC}$ and $\Delta \mathrm{NCO}$. It isn't significant and close to zero what reflects the absence of interaction between operating and investment activity. In reality, there are financial assets and liabilities that create a link between short-term and long-term operating accruals; and since these latter are isolated in a separate financial component, independence between the top and bottom of the balance sheet is observed.

TACC and their three components are significantly and positively associated (Richardson, and al., 2005). Reversibility of the accruals translates into negative and significant correlations between CFO and respectively TACC, $\triangle \mathrm{WC}, \triangle \mathrm{NCO}$ and $\triangle \mathrm{FIN}$.

Both $\triangle \mathrm{WC}$ and $\triangle \mathrm{NCO}$ are very strongly positively correlated with $\triangle \mathrm{FIN}(0.190$ and 0.308$)$. These results suggest that firms tend to increase financial liabilities to finance growth in their current and noncurrent operating assets. Finally, TACC and CFO are more sensitive to $\triangle F I N$ than to the other two components of accruals while EBEI is more correlated to $\triangle \mathrm{NCO}$.

\section{Empirical Results}

To test the differential implications of conditional conservatism on the components of accruals, it is imperative to attribute empirical evidence to conservatism.

\subsection{Detecting Conditional Conservatism}

To detect the practice of conditional conservatism by French companies, two measures are used: the Basu coefficient from the Basu model (1997) and the C-Score from the Khan \& Watts model (2009). The results of the Panel estimates of the Basu model (1997) are given in Table 5. 
Table 5. Results of Basu model estimates in panel data

\begin{tabular}{lll}
\hline Independent variable & Predicted sign & Period \\
& & $\mathbf{2 0 0 0 - 2 0 1 5}$ \\
\hline DR & $?$ & 0.001 \\
& - & $(0.401)$ \\
$\mathbf{R}$ & + & $\mathbf{0 . 0 1 9} * * *$ \\
$\mathbf{D R} \times \mathbf{R}$ & $(0.000)$ \\
& $?$ & $\mathbf{0 . 0 2 7} 7^{* * *}$ \\
Constant & & $(0.000)$ \\
& & $0.054^{* * *}$ \\
No. Of observations & $(0.000)$ \\
Modified Wald Test & 5245 \\
$\chi 2(331)$ & $3.4 \mathrm{e}+06^{* * *}$ \\
Wooldridge Test & $(0.000)$ \\
& $35.736^{* * *}$ \\
Wald $\chi \mathbf{2}(3)$ Test & $(0.000)$ \\
& $203.03^{* * *}$ \\
\hline
\end{tabular}

$* * *$ and $* *$ : p-values respectively significant at the $1 \%$ et $5 \%$ level.

Basu model (1997) is as follows : $X_{i t} / P_{i t-1}=\alpha_{0}+\alpha_{1} D_{i t}+\beta_{0} R_{i t}+\beta_{1} D_{i t} \times R_{i t}+\varepsilon_{i t}$

$\mathrm{X}_{\mathrm{i}}$ : Earnings per share for firm $\mathrm{i}$ in fiscal year $\mathrm{t}$,

$\mathrm{P}_{\mathrm{it}-1}$ : Price per share at the beginning of the fiscal year,

$\mathrm{R}_{\mathrm{it}}=\left(\mathrm{P}_{\mathrm{it}}-\mathrm{P}_{\mathrm{it}-1}\right) / \mathrm{P}_{\mathrm{it}-1}$ : Return on firm i from 9 months before fiscal year-end t to 3 months after fiscal year-end $\mathrm{t}$,

$\mathrm{DR}_{\mathrm{it}}$ : Dummy variable $=1$ if $\mathrm{R}_{\mathrm{it}}<0,=0$ otherwise.

The data from Worldscope cover the period: 2000-2015.

The test, Wald $\chi^{2}$, significant at the $1 \%$ level, indicates that the model is globally significant. The constant is significantly positive (1\%). According to Giner \& Rees (2001), a weak and positive constant is an indicator of ex-ante conservatism. It shows the gradual recognition of good news from previous periods. This type of conservatism is independent of news. It is linked to the financial statements.

Coefficients $\beta_{0}$ and $\beta_{1}$ are significantly positive $(1 \%)$. Both good and bad news is recognized immediately. In addition, the coefficient of the interaction $\beta_{1}$, which measures the incremental timeliness of earnings loss recognition, is significantly positive (1\%). This means that French listed companies practice conditional conservatism. This is in line with the results of Ding \& Stolowy (2006), which proved that during the 1990s, French firms practiced accounting conservatism.

C-Score is derived from Khan \& Watts model (2009). The latter is estimated by the two-step estimation technique of Fama \& Macbeth (1973). It is a method used to estimate parameters for asset pricing models such as the Capital Asset Pricing Model (CAPM). It consists of conducting a series of annual regressions in cross-section. Then, the mean coefficients over the period are recorded and their level of significance is evaluated under the assumption that they are independent values. This hypothesis is problematic if the estimated coefficients are strongly correlated over time (Cochrane, 2001). Therefore, it is imperative to study the heteroscedasticity and autocorrelation of residues. Regression (5) is estimated using the cross-section method of Famas-Macbeth (1973) with correction of heteroscedasticity based on the Newry \& West technique (1987) (Note 13). The results of estimation are illustrated in Table 5. They correspond to average values of the 16 estimated annual regressions for both the regression coefficients and the $\mathrm{R}^{2}$ coefficient of determination. 
Table 6. Mean Coefficients from Estimating Regression (5)

\begin{tabular}{|c|c|c|c|}
\hline Independant variable & Predicted Sign & Coefficient & t-statistic \\
\hline $\bar{D}$ it & & 0.049 & 0.32 \\
\hline $\mathrm{R}_{\mathrm{it}}$ & + & -0.048 & -0.18 \\
\hline $\mathrm{R}_{\mathrm{it}} \times \mathrm{Size}_{\mathrm{it}}$ & + & 0.008 & 0.51 \\
\hline $\mathrm{R}_{\mathrm{it}} \times \mathrm{M} / \mathrm{B}_{\mathrm{it}}$ & - & -0.017 & -1.32 \\
\hline $\mathrm{R}_{\mathrm{it}} \times \mathrm{Lev}_{\mathrm{it}}$ & - & -0.014 & -0.52 \\
\hline $\mathbf{D R}_{\mathrm{it}} \times \mathbf{R}_{\mathrm{it}}$ & + & $1.221 * *$ & 2.24 \\
\hline $\mathrm{DR}_{\mathrm{it}} \times \mathbf{R}_{\mathrm{it}} \times \mathrm{Size}_{\mathrm{it}}$ & - & $-0.063 * *$ & -2.33 \\
\hline $\mathbf{D R}_{\mathrm{it}} \times \mathbf{R}_{\mathrm{it}} \times \mathbf{M} / \mathbf{B}_{\mathrm{it}}$ & + & 0.024 & 0.90 \\
\hline $\mathbf{D R}_{\mathrm{it}} \times \mathbf{R}_{\mathrm{it}} \times \mathbf{L e v}_{\mathrm{it}}$ & + & 0.135 & 1.56 \\
\hline Size $_{\text {it }}$ & & 0.004 & 0.87 \\
\hline $\mathrm{M} / \mathrm{B}_{\mathrm{it}}$ & & 0.003 & 0.57 \\
\hline $\operatorname{Lev}_{\text {it }}$ & & -0.008 & -0.64 \\
\hline $\mathrm{DR}_{\mathrm{it}} \times \mathrm{Size}_{\mathrm{it}}$ & & -0.0006 & -0.09 \\
\hline $\mathrm{DR}_{\mathrm{it}} \times \mathrm{M} / \mathrm{B}_{\mathrm{it}}$ & & -0.010 & -0.88 \\
\hline $\mathrm{DR}_{\mathrm{it}} \times \mathrm{Lev}_{\mathrm{it}}$ & & -0.015 & -0.97 \\
\hline $\mathbf{R}^{2}$ & & $26.21 \%$ & \\
\hline
\end{tabular}

** Significant at the 5\% level.

Four parameter estimates in the table 5 are used to calculate the C-Score. They have the predicted sign. In addition, three of the four variables of interest are significant. The variable coefficient $(\mathrm{DR} \times \mathrm{R})$ is significantly positive $(5 \%)$. This result is consistent with the hypothesis of conditional conservatism practice by French firms. Moreover, the coefficient of the variable $(\mathrm{DR} \times \mathrm{R} \times \mathrm{Size})$ is significantly negative $(5 \%)$, which seems that large enterprises are not conservative. This is consistent with results of Lafond \& Watts (2008). The coefficient of (D x R x M/B) is insignificant, likely due to the buffer problem (Khan \& Watts, 2009). The conservatism of growth firms is not confirmed. Finally, the relatively significant coefficient ( $\mathrm{p}$-value $=0.14)$ of variable $(\mathrm{DR} \times \mathrm{R} \times \mathrm{LEV}$ ) is positive as expected. Thus, more levered firms tend to be conservative. The results are comparable to those of reference studies (Watts \& Khan, 2009 and $\mathrm{Li} \&$ Zhang, 2015). With an average coefficient of determination, $\mathrm{R}^{2}$ of $26.21 \%$, the overall significance of the estimated model is greater than respectively that of Watts \& Khan (2009) (24\%) and Li \& Zhang (2015) (13.55\%).

\subsection{Accruals Drivers and Conditional Conservatism}

Table 7 presents the empirical findings from estimating model (7) which is an adjusted version of Basu model. Our aim is to examine the impact of good and bad news on earnings, its two components (accruals and cash flows) and accruals drivers. Six regressions are estimated. The specification tests (Note 14) performed on these regressions showed the predominance of fixed-effect models (except for the regression $\mathrm{Y}=\mathrm{CFO}$ ). The presence of heteroscedasticity (Note 15) and/or AR(1) error autocorrelation was detected, hence the use of Generalized Least Squares (GLS) estimation. All regressions are significant at the threshold of $1 \%$ (Wald $\chi^{2}$ Test). 
Table 7. Impact of good and bad news on earnings components and accrual drivers

\begin{tabular}{|c|c|c|c|c|c|c|c|}
\hline Independant variable & Predicted sign & $Y=E B E I$ & $\mathrm{Y}=\mathrm{CFO}$ & $\mathbf{Y}=\mathbf{T A C C}$ & $\mathbf{Y}=\Delta \mathbf{R E V}$ & $\mathbf{Y}=\Delta \mathbf{R E C}$ & $Y=P P E$ \\
\hline \multirow[t]{2}{*}{ DR } & $?$ & 0.001 & 0.012 & -0.008 & -0.003 & $-0,0.007$ & -0.004 \\
\hline & & $(0.401)$ & $(0.138)$ & $(0.296)$ & $(0.513)$ & $(0.746)$ & $(0.739)$ \\
\hline \multirow[t]{2}{*}{$\mathbf{R}$} & - & $0.019 * * *$ & $0.053 * * *$ & $-0.050 * * *$ & -0.007 & -0.002 & $0.186^{* * * *}$ \\
\hline & & $(0.000)$ & $(0.000)$ & $(0.000)$ & $(0.236)$ & $(0.410)$ & $(0.000)$ \\
\hline \multirow[t]{2}{*}{$\mathbf{D R} \times \mathbf{R}$} & + & $0.027 * * *$ & 0.023 & $0.093 * * *$ & $0.051 * * *$ & $0.019 * * *$ & 0.056 \\
\hline & & $(0.000)$ & $(0.306)$ & $(0.000)$ & $(0.003)$ & $(0.003)$ & $(0.156)$ \\
\hline Constant & & $(0.000)$ & $(0.173)$ & $(0.000)$ & $(0.000)$ & $(0.000)$ & $(0.000)$ \\
\hline No. of observations & & 5245 & 5245 & 5245 & 5245 & 5245 & 5245 \\
\hline \multirow[t]{2}{*}{ Breusch-Pagan Test } & & - & $712.318 * * *$ & - & - & - & - \\
\hline & & - & $(0.000)$ & - & - & - & - \\
\hline \multirow[t]{2}{*}{ Modified Wald Test } & & $3.4 \mathrm{e}+06^{* * *}$ & - & $6.8 \mathrm{e}+06^{* * * *}$ & $4.6 \mathrm{e}+07 * * *$ & $2.5 \mathrm{e}+07$ & $8.5 \mathrm{e}+06^{* * * *}$ \\
\hline & & $(0.000)$ & - & $(0.000)$ & $(0.000)$ & $(0.000)^{* * * *}$ & $(0.000)$ \\
\hline Wooldridge Test & & $(0.000)$ & $(0.073)$ & $(0.001)$ & $(0.000)$ & $(0.199)$ & $(0.000)$ \\
\hline \multirow[t]{2}{*}{ Wald $\chi^{2}$ (3) Test } & & $203.03^{* * *}$ & $64.42^{* * *}$ & $29.77 * * *$ & $17.98 * * *$ & $15.94 * * *$ & $423.43^{* * * *}$ \\
\hline & & $(0.000)$ & $(0.000)$ & $(0.000)$ & $(0.000)$ & $(0.001)$ & $(0.000)$ \\
\hline
\end{tabular}

$* * *$ and $*$ : p-values respectively significant at the $1 \%$ and $10 \%$ level.

Derived Basu model (1997) is as follows : $\mathbf{Y}=\boldsymbol{\alpha}_{\mathbf{0}}+\boldsymbol{\alpha}_{\mathbf{1}} \mathbf{D} \mathbf{R}_{\mathrm{it}}+\boldsymbol{\beta}_{\mathbf{0}} \mathbf{R}_{\mathrm{it}}+\boldsymbol{\beta}_{\mathbf{1}} \mathbf{D} \mathbf{R}_{\mathrm{it}} \times \mathbf{R}_{\mathrm{it}}+\boldsymbol{\varepsilon}_{\mathrm{it}}$

$\mathrm{Y}$ is one at a time, Earnings before extraordinary items (EBEI), Cash flows (CF0), Total accruals, Change in revenue, Change in receivables, Property plant and equipment. All variables are standardized by market capitalization at the beginning of the year.

$\mathrm{R}_{\mathrm{it}}=\left(\mathrm{P}_{\mathrm{it}}-\mathrm{P}_{\mathrm{it}-\mathrm{l}}\right) / \mathrm{P}_{\mathrm{it}-1}$ : Return on firm i from 9 months before fiscal year-end $\mathrm{t}$ to 3 months after fiscal year-end $\mathrm{t}$,

$P_{i t-1}$ et $P_{i t}$ : Price per share respectively at the beginning and the end of the fiscal year $t$,

$\mathrm{DR}_{\mathrm{it}}$ : Dummy variable $=1$ if $\mathrm{R}_{\mathrm{it}}<0,=0$ otherwise.

The data from Worldscope cover the period: 2000-2015.

Operating cash flows (CFO) recognize the good news at a higher speed than the bad news ( $\beta 0$ is positively significant at the $1 \%$ level while $\beta 1$ is not significant). This result complies with the principle of realization of cash accounting. However, the asymmetry of recognition of losses and profits specific to cash flows, as illustrated by Basu (1997) and Pae, and al., (2005), is not verified. Looking over earnings (EBEI), the coefficients of respectively good news $\beta 0$ and bad news $\beta 1$ are positively significant at the $1 \%$ level: EBEI is affected by conservatism.

To avoid the confounding effect of cash flows from operations, we focus on the asymmetric timeliness of accruals rather than that of earnings: Y=TACC (Pae, 2007). TACC recognizes immediately bad news ( $\beta 1$ positively significant at the $1 \%$ level) and delay the recognition of good news ( $\beta 0$ negatively significant at the $1 \%$ level). This pattern of news recognition reflects a strict application of conditional conservatism, according to Basu (1997).

Collectively, the first three regressions indicate that the immediate recognition of bad news by EBEI is mainly due to the accrual component (TACC). The delay in recognizing good news through accruals is transformed into immediate recognition of good news through the cash flow component (CFO). In view of these results, we conclude that the accruals are the vector of transmission of conditional conservatism. Our findings are consistent with those of Basu (1997), Pope \& Walker (1999), Moreira \& Pope (2006) and Pae (2007) and refute those of Dimitropoulos (2008).

The accrual drivers $(\triangle \mathrm{REV}, \triangle \mathrm{REC}, \mathrm{PPE})$, usually used as explanatory variables in accrual models, show a different picture from the one discussed for EBEI, CFO and TACC. $\triangle$ REV and $\triangle$ REC recognize immediate bad new but not good news ( $\beta 1$ is positively significant at the $1 \%$ level while $\beta 0$ is not significant). Conversely, PPE is neutral in the recognition of bad news ( $\beta 1$ not significant) and recognize highly and immediately good news $(\beta 0=0.186$ significant at the $1 \%$ level). Respectively tests for difference and nullity of coefficients were conducted. The results are summarized in table 8 .

The first three lines of the table 8 support our previous results. All coefficients are statistically different from zero and the coefficients of good and bad news are statistically different for respectively regressions Y=EBEI and $\mathrm{Y}=\mathrm{TACC}$. The coefficients of good and bad news of the regression Y=CFO are not statistically different, which calls into question the preference for the recognition of good news by the CFO observed previously. 
Table 8 . Results of tests for respectively difference and nullity of coefficients $\beta_{0}$ and $\left(\beta_{0}+\beta_{1}\right)$

\begin{tabular}{llll}
\hline Dependant variable & $\boldsymbol{\beta}_{\mathbf{0}}(\mathbf{G N})$ & $\boldsymbol{\beta}_{\mathbf{0}}+\boldsymbol{\beta}_{\mathbf{1}}(\mathbf{B N})$ & $\mathbf{G N}=\mathbf{B N}$ \\
\hline EBEI & 0.019 & 0.047 & $*$ \\
CFO & 0.053 & 0.077 & $*$ \\
TACC & -0.050 & 0.043 & $*$ \\
$\Delta$ REV & $\mathbf{0 . 0 0 7}$ & 0.050 & $*$ \\
$\Delta$ REC & $\mathbf{0 . 0 0 2}$ & 0.017 & $=$ \\
PPE & 0.186 & 0.243 &
\end{tabular}

GN (BN) is the coefficient of the proxy for good (bad) news.

* means the coefficients are statistically different from each other at less than $1 \%$.

"=" indicates that the coefficients are not statistically different from each other.

Boldface numbers are not statistically different from zero at less than $1 \%$.

The significant nullity of the coefficients of the good news respectively of $\triangle \mathrm{REV}$ and $\triangle \mathrm{REC}$ confirms their neutrality in the recognition of profits. Their preference for immediate recognition of losses is also supported by the equality test of coefficients (the coefficients of good and bad news are statistically different at $1 \%$ Level). The apparent conservatism of $\triangle \mathrm{REV}$ and $\triangle \mathrm{REC}$ is probably made by decisions, which are authorized by Generally Accepted Accounting Principles, but which make it possible to circumvent the principle of realization. The coefficients of good and bad news of regression Y=PPE are not statistically different. This mitigates the previous finding that PPE immediately record good news. Only the PPE doesn't seem to be affected by conditional conservatism. This is in part consistent with the findings of Moreira \& Pope (2006) and Dimitropoulos (2008) that conservatism does not affect the accrual drivers.

Overall, accounting conservatism, through the asymmetry of recognition of losses and profits, affects both total accruals and two accrual drivers ( $\triangle \mathrm{REV}$ and $\triangle \mathrm{REC}$ ). An only accruals driver, PPE, isn't used to convey conditional conservatism.

\subsection{Discretionary Accruals and Conditional Conservatism}

Table 9 presents regression results of accruals and its non-discretionary/discretionary components on concurrent stock returns (9 regressions). The results of the specification tests (Note 16) heteroscedasticity test (Note 17) and autocorrelation of the errors AR (1) test (Note 18) call for the use of the least squares generalized method of estimation (GLS). The results of the estimates show that all regressions are significant at the $1 \%$ and $5 \%$ level (Wald $\chi 2$ Test). 
Table 9. Impact of good and bad news on Non-Discretionary and Discretionary accruals

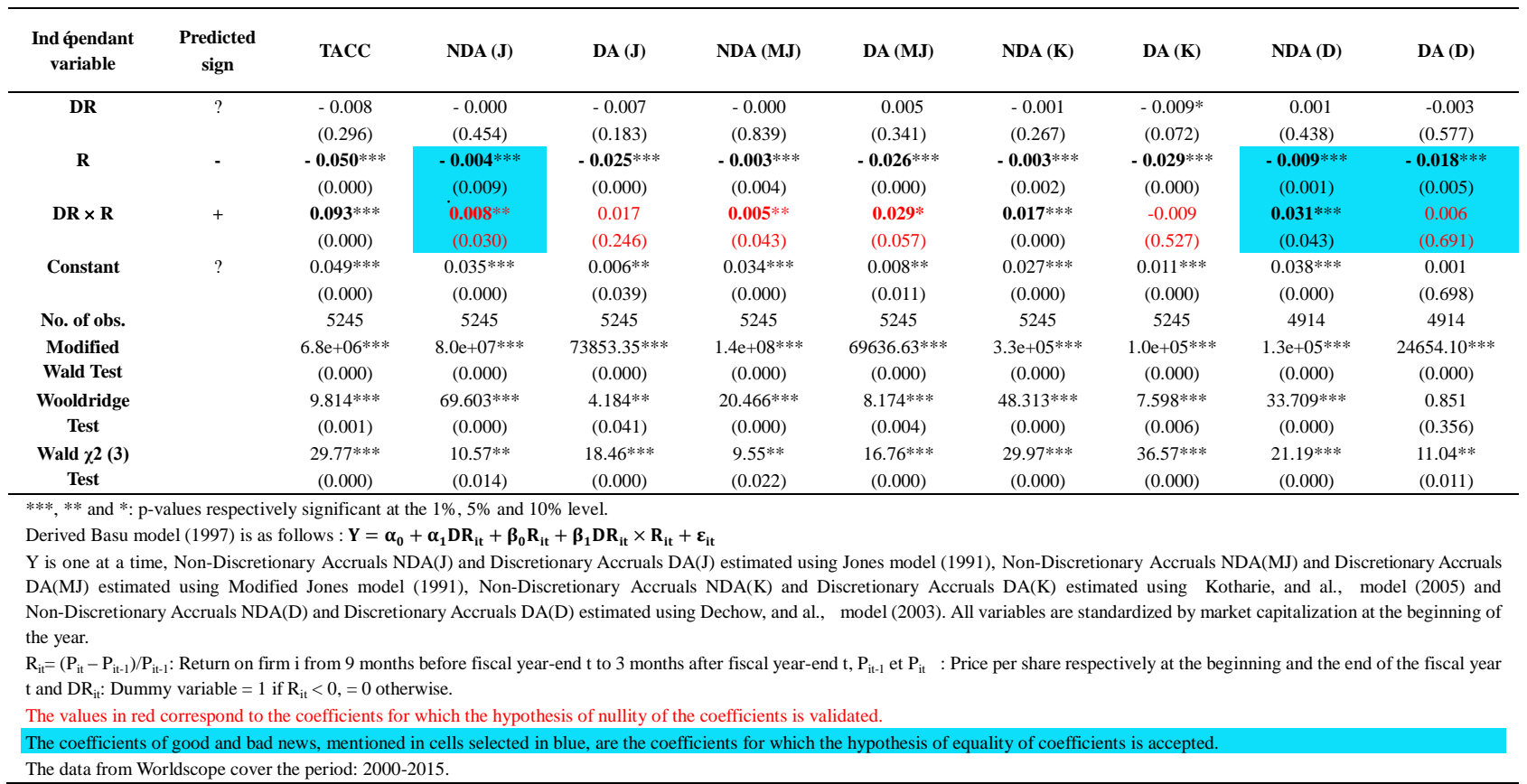

Non-Discretionary Accruals (NDA) regression constants are positively significant at the $1 \%$ level, reflecting the progressive recognition of NDA from previous periods. For all regressions, the coefficient of good news is significantly negative at the threshold of $1 \%$. Thus, both NDA and DA delay the recognition of the good news, which supported previous result, according to which the accruals defer the recognition of the gains. The coefficient of bad news is positively significant, at the threshold of $1 \%$ and $5 \%$, for all NDA regressions. According to the coefficient nullity test, the coefficient of bad news from regressions $Y=N D A(J)$ and $Y=N D A(M J)$ is significantly zero. These two findings show that non-discretionary accruals are used to convey conditional conservatism.

The coefficient of bad news is not significant for all AD regressions excepted regression $\mathrm{Y}=\mathrm{DA}(\mathrm{JM})$ ( $\beta 1$ is positively significant at the $10 \%$ level). Nevertheless, the hypothesis of nullity of coefficients are accepted for the coefficient of bad news of regression $\mathrm{Y}=\mathrm{DA}(\mathrm{JM})$. The hypothesis of equality of coefficients of good and bad news is accepted for regressions $\mathrm{Y}=\mathrm{DA}(\mathrm{K})$ and $\mathrm{Y}=\mathrm{DA}(\mathrm{D})$, which calls into question the immediate recognition of the good news already found for these two regressions. Thus, DA is neutral as to the immediate recognition of bad news. The delay in the recognition of good news is confirmed for DA(J) and DA(MJ) and confused for DA(K) and DA(D). Contrary to Pae (2007) and according to Dimitropoulos (2008), our results show that DA is not used as a vector for transmission of conservatism. In addition, discretionary accrual model does not affect the meaning of our results (Pae, 2007). Model improvements in Kotharie, and al., (2005) and Dechow, and al., (2003) appear to have little impact on the veracity of our results.

\subsection{Reliability Accruals and Conditional Accruals}

The heterogeneous behavior among different accruals components categorized by their reliability is examined below. To test whether accrual components exhibit varying degree of asymmetric timeliness, three regressions of components accruals on concurrent stock returns are estimated. Table 10 present regressions resulted. The specification tests (Note 19), heteroscedasticity test (Note 20) and autocorrelation of the errors AR (1) test (Note 21) call for the use of the least squares generalized method of estimation (GLS). The results of the estimates show that all regressions are significant at the $1 \%$ level (Wald $\chi 2$ Test). Regressions constants are positively significant at the $1 \%$ level, reflecting the progressive recognition respectively, of working capital $(\Delta \mathrm{WC})$, Non-current operating $(\Delta N C O)$ and financial accruals $(\Delta \mathrm{FIN})$ from previous periods.

Analogously to Total Accruals (TACC), its three components immediately recognize bad news and delay the recognition of good news (significant at $1 \%$ and $10 \%$ level). This result is consistent with Luo (2012) and Li \& Zhang (2015).

In addition, equality coefficients Tests conclude that the null hypothesis of equality of the coefficients of good and bad news is rejected for the three regressions. However, nullity coefficients Tests show that the coefficients of the 
bad news from the regressions $\mathrm{Y}=\Delta \mathrm{WC}$ and $\mathrm{Y}=\Delta \mathrm{FIN}$ is significantly zero. Asymmetric timeliness are reflected to a greater degree in Non-current operating accruals relative to working capital and financial accruals. Thus, we can conclude that conditional conservatism is operated differently through the three components of the accruals.

Table 10. Asymmetric timeliness and accrual reliability

\begin{tabular}{|c|c|c|c|c|c|c|c|c|c|c|c|c|}
\hline \multirow{2}{*}{$\begin{array}{l}\text { Indépendant } \\
\text { Variable }\end{array}$} & \multirow{2}{*}{$\begin{array}{c}\text { Pred. } \\
\text { Sign }\end{array}$} & \multirow{2}{*}{$\begin{array}{c}\text { Total } \\
\text { accruals } \\
\text { TACC }\end{array}$} & \multicolumn{3}{|c|}{ Working capital accruals } & \multicolumn{3}{|c|}{ Non-current operating accruals } & \multicolumn{4}{|c|}{ Financial accruals } \\
\hline & & & $\Delta \mathbf{W C}$ & $\triangle \mathrm{COA}$ & $\Delta \mathrm{COL}$ & $\triangle \mathrm{NCO}$ & $\triangle \mathrm{NCOA}$ & $\triangle \mathrm{NCOL}$ & $\Delta$ FIN & $\Delta \mathrm{STI}$ & $\Delta \mathrm{LTI}$ & $\Delta$ FINL \\
\hline DR & $?$ & $\begin{array}{l}-0.008 \\
(0.296)\end{array}$ & $\begin{array}{l}-0.003 \\
(0.116)\end{array}$ & $\begin{array}{l}-0.002 \\
(0.531)\end{array}$ & $\begin{array}{l}-0.002 \\
(0.465)\end{array}$ & $\begin{array}{c}-0.0005 \\
(0.891)\end{array}$ & $\begin{array}{l}-0.002 \\
(0.584)\end{array}$ & $\begin{array}{l}-0.001 \\
(0.181)\end{array}$ & $\begin{array}{l}-0.005 \\
(0.250)\end{array}$ & $\begin{array}{l}0.0009 \\
(0.308)\end{array}$ & $\begin{array}{l}-0.0001 \\
(0.602)\end{array}$ & $\begin{array}{l}-0.0022 \\
(0.392)\end{array}$ \\
\hline $\mathbf{R}$ & - & $\begin{array}{c}-\mathbf{0 . 0 5 0} 0^{* * * *} \\
(0.000)\end{array}$ & $\begin{array}{c}-\mathbf{0 . 0 2 3}^{* * * *} \\
(0.000)\end{array}$ & $\begin{array}{c}-\mathbf{0 . 0 0 8}^{* * *} \\
(0.017)\end{array}$ & $\begin{array}{c}0.003 \\
(0.361)\end{array}$ & $\begin{array}{c}-\mathbf{0 . 0 1 6}^{* * * * *} \\
(0.000)\end{array}$ & $\begin{array}{c}-\mathbf{0 . 0 1 3}^{* * * *} \\
(0.001)\end{array}$ & $\begin{array}{c}-0.0004 \\
(0.693)\end{array}$ & $\begin{array}{l}-\mathbf{~ 0 . 0 1 1 *}^{*} \\
(0.061)\end{array}$ & $\begin{array}{c}\mathbf{0 . 0 0 6} \text { **** } \\
(0.000)\end{array}$ & $\begin{array}{l}\text { 0.006* } \\
(0.071)\end{array}$ & $\begin{array}{c}-\mathbf{- 0 . 0 1 6} \text { (*** }^{*} \\
(0.071)\end{array}$ \\
\hline $\mathbf{D R} \times \mathbf{R}$ & + & $\begin{array}{c}\mathbf{0 . 0 9 3} \text { **** } \\
(0.000)\end{array}$ & $\begin{array}{c}\mathbf{0 . 0 2 8}^{* * * *} \\
(0.000)\end{array}$ & $\begin{array}{c}\mathbf{0 . 0 3 2} 2^{* * * *} \\
(0.000)\end{array}$ & $\begin{array}{l}\mathbf{0 . 0 2 0}^{* * *} \\
(0.022)\end{array}$ & $\begin{array}{c}\mathbf{0 . 0 3 6}^{\text {**** }} \\
(0.000)\end{array}$ & $\begin{array}{c}\mathbf{0 . 0 3 5}^{* * * *} \\
(0.001)\end{array}$ & $\begin{array}{c}0.004 \\
(0.103)\end{array}$ & $\begin{array}{l}\mathbf{0 . 0 2 3}^{*} \\
(0.090)\end{array}$ & $\begin{array}{l}-0.002 \\
(0.476)\end{array}$ & $\begin{array}{l}0.0002 \\
(0.811)\end{array}$ & $\begin{array}{l}\text { 0.014* } \\
(0.054)\end{array}$ \\
\hline Constant & $?$ & $\begin{array}{c}0.049^{* * * *} \\
(0.000)\end{array}$ & $\begin{array}{c}0.005^{* * * *} \\
(0.000)\end{array}$ & $\begin{array}{c}0.020^{* * * *} \\
(0.000)\end{array}$ & $\begin{array}{c}0.017^{* * * * *} \\
(0.000)\end{array}$ & $\begin{array}{c}0.024^{* * * *} \\
(0.000)\end{array}$ & $\begin{array}{c}0.020^{* * * *} \\
(0.000)\end{array}$ & $\begin{array}{c}0.004^{* * * *} \\
(0.000)\end{array}$ & $\begin{array}{c}0.015^{* * * *} \\
(0.000)\end{array}$ & $\begin{array}{l}-0.0003 \\
(0.589)\end{array}$ & $\begin{array}{c}0.0006^{* * * *} \\
(0.001)\end{array}$ & $\begin{array}{c}0.006^{* * * *} \\
(0.000)\end{array}$ \\
\hline \multicolumn{2}{|l|}{ No. of obs. } & 5245 & 5245 & 5245 & 5245 & 5245 & 5245 & 5245 & 5245 & 5245 & 5245 & 5245 \\
\hline \multicolumn{2}{|l|}{ Breusch-Pagan } & - & - & - & - & - & - & $6864.3^{* * * *}$ & - & $2526.8^{* * * *}$ & $2999.4 * * *$ & - \\
\hline \multicolumn{2}{|l|}{ Modified } & $\begin{array}{c}6.8 \mathrm{e}+06^{* * * * *} \\
(0.000)\end{array}$ & $\begin{array}{c}1.9 \mathrm{e}+07^{*} * * \\
(0.000)\end{array}$ & $\begin{array}{c}4.6 \mathrm{e}+07 * * * * \\
(0.000)\end{array}$ & $\begin{array}{c}4.4 \mathrm{e}+07^{\text {**** }} \\
(0.000)\end{array}$ & $\begin{array}{c}1.1 \mathrm{e}+08^{* * * *} \\
(0.000)\end{array}$ & $\begin{array}{c}1.9 \mathrm{e}+08^{* * * *} \\
(0.000)\end{array}$ & - & $\begin{array}{c}1.2 \mathrm{e}+08^{* * * *} \\
(0.000)\end{array}$ & - & - & $\begin{array}{c}3.7 \mathrm{e}+07^{\text {***** }} \\
(0.000)\end{array}$ \\
\hline \multicolumn{2}{|l|}{ Wooldridge } & $\begin{array}{c}9.814^{* * * *} \\
(0.001)\end{array}$ & $\begin{array}{c}0.229 \\
(0.632)\end{array}$ & $\begin{array}{c}1.735 \\
(0.188)\end{array}$ & $\begin{array}{c}0.825 \\
(0.365)\end{array}$ & $\begin{array}{l}4.043^{* * *} \\
(0.045)\end{array}$ & $\begin{array}{c}11.345^{* * *} \\
(0.000)\end{array}$ & $\begin{array}{c}2.652 \\
(0.104)\end{array}$ & $\begin{array}{c}0.045 \\
(0.831)\end{array}$ & $\begin{array}{c}2.512 \\
(0.114)\end{array}$ & $\begin{array}{l}2.729^{*} \\
(0.099)\end{array}$ & $\begin{array}{c}0.197 \\
(0.657)\end{array}$ \\
\hline \multicolumn{2}{|l|}{ Wald $\chi^{2}(3)$} & $\begin{array}{c}29.77^{\text {***** }} \\
(0.000)\end{array}$ & $\begin{array}{c}63.76^{* * * *} \\
(0.000)\end{array}$ & $\begin{array}{c}18.50^{* * * * *} \\
(0.000)\end{array}$ & $\begin{array}{c}29.91 * * * * \\
(0.000)\end{array}$ & $\begin{array}{c}19.96^{* * * * *} \\
(0.000)\end{array}$ & $\begin{array}{c}17.10^{* * * *} \\
(0.000)\end{array}$ & $\begin{array}{c}14.09^{* * * *} \\
(0.002)\end{array}$ & $\begin{array}{c}6.61^{*} \\
(0.085)\end{array}$ & $\begin{array}{c}26.21 \\
(0.002) * * * *\end{array}$ & $\begin{array}{c}29.34 * * * * \\
(0.000)\end{array}$ & $\begin{array}{c}31.33^{* * * * *} \\
(0.000)\end{array}$ \\
\hline \multirow{2}{*}{\multicolumn{13}{|c|}{$\begin{array}{l}* * * * * \text { and } * \text { : p-values respectively significant at the } 1 \%, 5 \% \text { and } 10 \% \text { level. } \\
\text { Derived Basu model }(1997) \text { is as follows : } \mathbf{Y}=\boldsymbol{\alpha}_{\mathbf{0}}+\boldsymbol{\alpha}_{\mathbf{1}} \mathbf{D} \mathbf{R}_{\text {it }}+\boldsymbol{\beta}_{\mathbf{0}} \mathbf{R}_{\mathrm{it}}+\boldsymbol{\beta}_{\mathbf{1}} \mathbf{D} \mathbf{R}_{\mathbf{i t}} \times \mathbf{R}_{\mathrm{it}}+\boldsymbol{\varepsilon}_{\mathrm{it}} \\
\mathrm{Y} \text { is one at a time, total accruals (TACC), Working capital accruals }(\Delta \mathrm{WC}) \text { which assets component }(\Delta \mathrm{COA}) \text { and liabilities component }(\Delta \mathrm{COL}), \text { Non-current operating accruals }(\Delta \mathrm{NCO}) \text { which assets component } \\
(\Delta \mathrm{NCOA}) \text { and liabilities component }(\Delta \mathrm{NCOL}) \text { and financial accruals }(\Delta \mathrm{FIN}) \text { which assets components }(\Delta \mathrm{STI}),(\Delta \mathrm{LTI}) \text { and liabilities component }(\Delta \mathrm{FINL}) \text {. }\end{array}$}} \\
\hline & & & & & & & & & & & & \\
\hline \multicolumn{13}{|c|}{ All variables are standardized by market capitalization at the beginning of the year. } \\
\hline \multicolumn{13}{|c|}{$\mathrm{R}_{\mathrm{it}}=\left(\mathrm{P}_{\mathrm{it}}-\mathrm{P}_{\mathrm{it}-1}\right) / \mathrm{P}_{\mathrm{it}-1}:$ Return on firm i from 9 months before fiscal year-end $\mathrm{t}$ to 3 months after fiscal year-end $\mathrm{t}$, } \\
\hline \multicolumn{13}{|c|}{$P_{i t-1}$ et $P_{i t}:$ Price per share respectively at the beginning and the end of the fiscal year $t$, } \\
\hline \multicolumn{13}{|c|}{$\mathrm{DR}_{\mathrm{it}}$ : Dummy variable $=1$ if $\mathrm{R}_{\mathrm{it}}<0,=0$ otherwise. } \\
\hline \multicolumn{13}{|c|}{ The values in red correspond to the coefficients for which the hypothesis of nullity of the coefficients is validated. } \\
\hline
\end{tabular}

To refine precedent results, conservatism index, as presented by Luo (2012), is calculated. The results obtained are reported in Table 11.

Table 11. Conservatism index for the three components of accruals

\begin{tabular}{llll}
\hline Conservatism index & $\Delta \mathbf{W C}$ & $\Delta$ NCO & $\Delta$ FIN \\
\hline$\left(\boldsymbol{\beta}_{1 \mathbf{x}}+\boldsymbol{\beta}_{2 \mathrm{x}}\right) / \boldsymbol{\beta}_{\mathbf{1 x}}$ & 2.217 & 3.25 & 3.09 \\
Reliability & Medium & Low/Medium & High \\
Degree of conservatism & Low & Medium & Medium \\
\hline
\end{tabular}

The values of conservatism index are calculated from coefficients all significant of at $1 \%$ level except for those relating to financial accruals which are significant at $10 \%$ level.

\section{Index $=\left(\beta_{1 \mathrm{x}}+\beta_{2 \mathrm{x}}\right) / \beta_{1 \mathrm{x}}$, measuring the times which component accruals is as sensitive to negative returns as} to positive ones.

Analogously to predictions, non-current operating accruals $(\triangle \mathrm{NCO})$ are the most conservative, which corroborates the results of Tazawa (2003) and Luo (2012) and contradicts those of Li \& Zhang (2015). Paradoxically, working capital accruals $(\triangle \mathrm{WC})$ is the least conservative among the three components accruals while Luo (2012) and $\mathrm{Li}$ and Zhang (2015) conclude that the degree of conservatism of this component should be intermediate in degrees of conservatism of the two other components.

Consistent with predictions, Luo (2012) shows that financial component $(\Delta \mathrm{FIN})$ is the least conservative, while Li \& Zhang (2015) prove that it is the most conservative. Our results do not support any of these studies since we conclude that financial accruals $(\Delta \mathrm{FIN})$ are moderately conservative despite their high degree of reliability. Managers appear not to comply with strict verifiability requirements when recognizing gains and losses related to reliable accruals $(\Delta \mathrm{FIN})$.

In view of these mixed results, we examined the degree of conservatism respectively, of Assets components and Liabilities components for the three components accruals. The results are reproduced in Table 12. They show that respectively Assets components and Liabilities components of working capital accruals do not convey conservatism in the same way. 
Thus, the asset component of current operating accruals $(\triangle \mathrm{COA})$ delays the recognition of good news and immediately notice bad news, this is made possible thanks to low reliability of inventories and receivables. A liability component of current operating accruals $(\triangle \mathrm{COL})$ is neutral in the recognition of gains and advance the recognition of losses (coefficient significant at the 5\% level). This low level of conservatism is due to the objectivity required in accounting for operating payables since deadlines are set by the suppliers. Our results are consistent with Richardson, et al., (2005) predictions. Thus, low conservatism of working capital accruals ( $\triangle \mathrm{WC}$ ) is really due to the liability component whose accounting is strict and very reliable.

The high conservatism of non-current operating accruals $(\triangle \mathrm{NCO})$ is confirmed through a single component which is asset one of non-current operating accruals ( $\triangle \mathrm{NCOA})$. Indeed, liability component of non-current operating accruals $(\triangle \mathrm{NCOL})$ is neutral in recognition of both losses and profits. In fact, their accounts, long-term payables, deferred taxes and postretirement benefit obligations, have varying degrees of reliability. In addition, in view of the descriptive statistics, a liability component of non-current operating accruals $(\triangle \mathrm{NCOL})$ is negligible as opposed to asset component ( $\triangle \mathrm{NCOA})$. As per Richardson, et al., (2005), the apparent and increased conservatism of the asset components of non-current operating accruals $(\triangle \mathrm{NCOA})$ is permitted through the subjectivity of decisions relating to the accounting of PP\&E and intangibles such as the amortization and write-down decisions. As a result, conservatism of non-current operating accruals $(\triangle \mathrm{NCO})$ is conveyed exclusively by asset component characterized by low reliability.

Finally, the examination of the asymmetrical recognition of good and bad news relating to assets and liability components of financial accruals shows that the two assets components of financial accruals (Short-term Investments $\Delta$ STI and Long-term Investments $\Delta$ LTI) do not convey conservatism. Indeed, coefficients respectively, of bad news and good news are insignificant and close to zero. In addition, the null hypothesis of equal coefficients of good and bad news is accepted for both regressions Y= STI and Y= LTI; this supports neutrality of these two components on recognition of new. Consistent with Richardson, et al., (2005), strict subjectivity and reliability are imposed when accounting current and non-current financial assets (investment and equity securities).

Only liability component of financial accruals $(\Delta \mathrm{FINL})$ is responsible for the observed conservatism of financial accruals $(\Delta \mathrm{FIN})$. This conservatism is mixed since the coefficient of bad news is significant $(10 \%)$ but it is significantly equal to zero according to the test of nullity of coefficients. The delay in recognizing good news is nevertheless significant (1\%). Despite high reliability, advocated by Richardson, et al., (2005), a liability component of financial accruals $(\triangle \mathrm{FINL})$ is used to delay recognition of good news. The anticipation of bad news by this component of accruals remains to be confirmed. Thus, the conservatism conveyed by financial accruals is mixed. However, if it is verified, it can only be operated by liability component.

In view of all these results, total accruals transmit conservatism through assets components, respectively, of current operating accruals $(\triangle \mathrm{COA})$ and non-current operating accruals $(\triangle \mathrm{NCOA})$ and a liability component of financial accruals $(\triangle \mathrm{FINL})$.

Table 12 presents conservatism index calculated for assets components respectively, of current operating accruals $(\triangle \mathrm{COA})$ and non-current operating accruals $(\triangle \mathrm{NCOA})$ and a liability component of financial accruals $(\Delta \mathrm{FINL})$.

Table 12. Conservatism index for Assets and Liabilities components of accruals

\begin{tabular}{llll}
\hline Conservatism index & $\Delta$ COA & $\Delta$ NCOA & $\Delta$ FINL \\
\hline$\left(\beta_{1 \mathbf{x}}+\boldsymbol{\beta}_{2 \mathbf{x}}\right) / \beta_{1 \mathrm{x}}$ & 5 & 3.692 & 1.875 \\
Reliability & Low & Low & High \\
Degree of conservatism & High & Medium & Low \\
\hline
\end{tabular}

The values of conservatism index are calculated from coefficients all significant at $1 \%, 5 \%$ and $10 \%$ level.

Index $=(\beta 1 x+\beta 2 x) / \beta 1 x$, measuring the times which Assets and Liabilities components accruals are as sensitive to negative returns as to positive ones.

In the light of these new measures, we refine our previous conclusions. Thus, according to predictions, liability component of financial accruals $(\triangle \mathrm{FINL})$ is the least conservative. This result is consistent with Luo (2012) but contradictory to Li \& Zhang (2015). Assets components, respectively, of current operating accruals $(\triangle \mathrm{COA})$ and non-current operating accruals $(\triangle \mathrm{NCOA})$ are conservative with more pronounced conservatism for current operating (Tazawa, 2003). This result is consistent with the predictions since the debate is still relevant as regards the degree of conservatism of current and non-current operating accruals. 


\section{Conclusions}

Applied to the French context, this study examined the unequal impact of conditional conservatism on components accruals. The sample of the study was an unbalanced panel of 331 French companies listed on Euronext Paris during the period time going from 2000 till 2015. Basu (1997) and Khan and Watts (2009) models were used to detect conditional conservatism. Estimation results revealed that both good and bad news are recognized immediately. So, French listed companies practice conditional conservatism. The major result of our study is that French companies favor the use of accruals to promote conditional conservatism. In fact, total accruals recognize immediate bad news and delay the recognition of good news. This pattern of news recognition reflects a strict application of conditional conservatism, according to Basu (1997). Furthermore, only non-discretionary accruals are used and discretionary accruals are neutral for transmission of conservatism. However, contrary to predictions, accrual drivers appear to be affected by conditional conservatism with the exception of PP\&E. Among the three components of the accruals, the current operating component is the preferred tool for the transmission of conditional conservatism. The latter's low reliability permits an asymmetry of recognition of losses and gains.

Our empirical study has both strengths and weaknesses. The strengths are primarily the sample size, diversity of assumptions tested, the use of comprehensive accrual measurement (Richardson, and al., 2005) and the use of two conditional conservatism measures (Basu model (1997) and C-Score measurement). Its weakness is that the Basu model (1997) may lead to a biased estimate of the degree of conservatism. The debate about the existence and meaning of the bias of the model is still ongoing. Thus, Gigler \& Hemmer (2001) and Dietrich, and al., (2007) conclude that there is an upward bias, while Givoly, and al., (2007) indicate that the direction of bias is undetermined.

The major limitation of our work is the poor specification due to the use of Basu model (1997), we propose, as future prospects, to resume our work by bringing to this model the improvements advocated by recent studies. For example, Huang, Tian \& Wirjanto, (2011) recommend that the company's sector-specific characteristics to be considered in the Basu model (1997) specification. Patatoukas \& Thomas (2016), of their shares, propose to break down both the stock market return and the accounting result by composing expected and unexpected component since the latter component was at the origin of the measurement bias of the Basu model (1997).

\section{References}

Ahmed, A.S. \& Duellman, S. (2007). Accounting conservatism and board of director characteristics: An empirical analysis. Journal of Accounting and Economics, (2-3), 411-437. http://dx.doi.org/10.1016/j.jacceco.2007.01.005

Basu, S. (1997). The conservatism principle and the asymmetric timeliness of earnings. Journal of Accounting \& Economics, 24, 3-37. https://doi.org/10.1016/S0165-4101(97)00014-1

Ball, R., Kothari, S.P. \& Robin, A. (2000). The effect of international institutional factors on the properties of accounting earnings. Journal of Accounting and Economics, 29, 1-51. https://doi.org/10.1016/S0165-4101(00)00012-4

Ball, R., Robin, A. \& Sadka, G. (2005). Is accounting conservatism due to debt or share markets? A test of "contracting" versus "value relevance" theories of accounting, Working Paper University of Chicago.

Ball, R. \& Shivakumar, L. (2006). The Role of Accruals in Asymmetrically Timely Gain and Loss Recognition. Journal of Accounting Research, 44(2), 207-242. https://doi.org/10.1111/j.1475-679X.2006.00198.x

Ball, R., Robin, A. \& Sadka, G. (2008). Is financial reporting shaped by equity markets or by debt markets? An international study of timeliness and conservatism. Review of Accounting Studies, 13(2-3), 168-205. https://doi.org/10.1007/s11142-007-9064-x

Beatty, A. (2007). Discussion of "asymmetric timeliness of earnings, market-to-book and conservatism in financial reporting". Journal of Accounting and Economics, 44(1-2), 32-35. https://doi.org/10.1016/j.jacceco.2007.01.003

Beatty, A., Weber, J. \& Yu, J.J. (2008). Conservatism and Debt. Journal of Accounting and Economics, 45(2-3), 154-174. https://doi.org/10.1016/j.jacceco.2008.04.005

Beekes, W., Pope, P. \& Young, S. (2004). The link between earnings timeliness, earnings conservatism and board composition: evidence from the UK. Corporate Governance: An International Review, 12, 47-59. https://doi.org/10.1111/j.1467-8683.2004.00342.x

Bushman, R.M. \& Piotroski, J.D. (2006). Financial reporting incentives for conservative accounting: The influence of legal and political institutions, 42(1-2), 107-148. https://doi.org/10.1016/j.jacceco.2005.10.005 
Cochrane, J.H. (2001). Asset pricing. book Published by Princeton University. https://doi.org/10.1016/j.jebo.2005.08.001

Dechow, P. M. (1994). Accounting earnings and cash flows as measures of firm performance: The role of accounting accruals. Journal of Accounting and Economics, 18, 3-42. https://doi.org/10.1016/0165-4101(94)90016-7

Dechow, P.M., Sloan, R.G. \& Sweeney, A.P. (1995). Detecting earnings management. The Accounting Review, 70(2), 193-225.

Dechow, P.M. Richardson, S.A. \& Tuna, I. (2003). Why Are Earnings Kinky? An Examination of the Earnings Management Explanation. Review of Accounting Studies, 8(2), 355-384. https://doi.org/10.1023/A:1024481916719

DeFond, M.L. \& Jiambalvo, J. (1994). Debt covenant violation and manipulation of accruals. Journal of Accounting and Economics, 17, 145-176. https://doi.org/10.1016/0165-4101(94)90008-6

Dietrich, J., Muller, K. \& Riedl, E. (2007). Asymmetric timeliness tests of accounting conservatism. Review of Accounting Studies, 12(1), 95-124. https://doi.org/10.1007/s11142-006-9023-y

Dimitropoulos, P.E. (2008). Conservatism and Accruals: Are They Interactive? Evidence from the Greek Capital Market. International Journal of Business and Management, 3(10), 113-121. https://doi.org/10.5539/ijbm.v3n10p113

Ding, Y. \& Stolowy, H. (2006). Timeliness and conservatism: Changes over time in the properties of accounting income in France. Review of Accounting and Finance, 5(2), 92-107. https://doi.org/10.1108/14757700610668949

Dumontier, P. \& Labelle, R. (1993). Accounting earnings and firm valuation: the French case. The European Accounting Review, 7, 163-183. https://doi.org/10.1080/096381898336439

Easton, P., Harris, T. \& Ohlson I. (1992). Aggregate accounting earnings can explain most of security returns. Journal of Accounting and Economics, 9, 119-142. https://doi.org/10.1016/0165-4101(92)90015-T

Fama, E.F. \& MacBeth, J.D. (1973). Risk, Return, and Equilibrium: Empirical Tests. Journal of Political Economy, 81(3), 607-636. https://doi.org/10.1086/260061

Giner, B. \& Rees, W.P. (2001). On the Asymmetric Recognition of Good and Bad News in France, Germany and the United Kingdom. Journal of Business Finance \& Accounting, 28(9-10), 1333-1349. https://doi.org/10.1111/1468-5957.00416

Givoly, D. \& Hayn, C. (2000). The changing time series properties of earnings, cash flows and accruals: has financial reporting become more conservative? Journal of Accounting \& Economics, 29, 287-320. https://doi.org/10.1016/S0165-4101(00)00024-0

Givoly, D., Hayn, C.K. \& Natarajan, A. (2007). Measuring reporting conservatism. The Accounting Review, 82, 65-106. https://doi.org/10.2308/accr.2007.82.1.65

Healy, P.M. (1985). The effect of bonus schemes on accounting decisions. Journal of Accounting and Economics, 7 , 85-107. https://doi.org/10.1016/0165-4101(85)90029-1

Hsu A., O'Hanlon, J. \& Peasnell, K. (2012). The Basu Measure as an Indicator of Conditional Conservatism: Evidence from UK Earnings Components. European Accounting Review, 21(1), 87-113. https://doi.org/10.1080/09638180.2011.558296

Huang, A.G., Tian, Y. \& Wirjanto, T.S. (2011). Re-Examing accounting conservatism: The importance of adjusting for firm heterogeneity, Working Paper.

Jones, J. (1991). Earnings Management During Import Relief Investigations. Journal of Accounting Research, 29(2), 193-228. https://doi.org/10.2307/2491047

Kang, S. \& Sivaramakrishnan, K. (1995). Issues in testing earnings management and an instrumental variable approach. Journal of Accounting Research, 33(2), 353-367. https://doi.org/10.2307/2491492

Khan, M. \& Watts, R.L. (2009). Estimation and empirical properties of a firm-year measure of accounting conservatism. Journal of Accounting and Economics, 48(2-3), 132-150. https://doi.org/10.1016/j.jacceco.2009.08.002

Kothari, S.P., Sabino, J.S. \& Zach, T. (2005). Implications of survival and data trimming for tests of market $\begin{array}{lllll}\text { efficiency. Journal of Accounting and } & \text { Economics, } & 39(1), & \text { 129-161. }\end{array}$ 
https://doi.org/10.1016/j.jacceco.2004.02.003

Krishnan, G. (2005). Did Houston Clients of Arthur Andersen Recognize Publicly Available Bad News in a Timely Fashion? Contemporary Accounting Research, 22, 165-193. https://doi.org/10.1506/EGQD-BTG1-4RHD-7MU6

LaFond, R. \& Roychowdhury, S. (2008). Managerial ownership and accounting conservatism. Journal of accounting research, 46(1), 101-135. https://doi.org/10.1111/j.1475-679X.2008.00268.x.

LaFond, R. \& Watts, R.L. (2008). The Information Role of Conservatism. The Accounting Review, 83(2), 447-478. https://doi.org/10.2308/accr.2008.83.2.447.

Li, Y. \& Zhang,W. (2015). Conditional conservatism and persistence of accrual components. Revue canadienne des sciences de l'administration, 32, 15-29. https://doi.org/10.1002/cjas.1305

Lobo, G.J. \& Zhou, J. (2006). Did Conservatism in Financial Reporting Increase after the Sarbanes - Oxley Act? Initial Evidence. Accounting, 20(1), 57-73. https://doi.org/10.2308/acch.2006.20.1.57

Luo, C. (2012). Conditional Conservatism and Accruals Reliability, Master Thesis of Accountancy and Control Faculty of Economics and Business University of Amsterdam.

Newey, W.K \& West, K.D. (1987). A Simple, Positive Semi-definite, Heteroskedasticity and Autocorrelation Consistent Covariance Matrix. Econometrica, 55(3), 703-708. https://doi.org/10.2307/1913610

Moreira, A.C. \& Pope, P.F. (2006). Unequal Impact of Conservatism on Accrual Measures and Drivers: Implications for the Specification of Accrual Models, CETE Discussion Papers.

Pae, J., Thornton; D. B. \& Welker, M. (2005). The link between earnings conservatism and the price-to-book ratio. Contemporary Accounting Research, 22(3), 693-717. https://doi.org/10.1506/9FDN-N6ED-LJE9-A1HL

Pae, J. (2007). Unexpected accruals and conditional accounting conservatism. Journal of Business Finance \& Accounting, 34(5-6), 681-704. https://doi.org/10.1111/j.1468-5957.2007.02018.x

Patatoukas, P.N. \& Thomas, J.K. (2016). Placebo tests of conditional conservatism. The Accounting Review, 91(2), 625-648. https://doi.org/10.2308/accr-51179

Peasnell, K.V., Pope, P.F. \& Young, S. (2000). Detecting earnings management using cross-sectional abnormal accruals models, Working Paper. https://doi.org/10.1080/00014788.2000.9728949

Pope, P.F \& Walker, M. (1999). International differences in the timeliness, conservatism, and classification of earnings. Journal of Accounting Research, 37, 53-89. https://doi.org/10.2139/ssrn.185308

Richardson, S.A., Sloan, R.G., Soliman, M.T. \& Tuna, I. (2005). Accrual reliability, earnings persistence and stock prices. Journal of Accounting and Economics, 39, 437-485. https://doi.org/10.1016/j.jacceco.2005.04.005

Roychowdhury, S. \& Watts, R. L. (2007). Asymmetric timeliness of earnings, market-to-book and conservatism in financial reporting. Journal of Accounting and Economics, 44(1-2), 2-31. https://doi.org/10.1016/j.jacceco.2006.12.003

Sivakumar, K. \& Waymire, G. (2003). Enforceable Accounting Rules and Income Measurement by Early 20th Century Railroads. Journal of Accounting Research, 41(2), 397-432. https://doi.org/10.1111/1475-679X.00110.

Tazawa, M. (2003). The Timeliness of Earnings and Accruals under Conservatism in Japan, Nagoya City University, Discussion Papers in Economics, $\mathrm{N}^{\circ}$ 334. https://doi.org/10.2139/ssrn.408360

Watts, R.L. (2003). Conservatism in accounting part I: Explanations and implications. Accounting Horizons, 17(3), 207-221. https://doi.org/10.2308/acch.2003.17.3.207.

$\mathrm{Xi}$, L. (2015). Accounting conservatism and the cost of capital: international analysis. Journal of Business Finance \& Accounting, 42(5-6), 555-582. https://doi.org/10.1111/jbfa.12121.

Zhang, J. (2008). The contracting benefits of accounting conservatism to lenders and borrowers. Journal of Accounting and Economics, 45(1), 27-54. https://doi.org/10.1016/j.jacceco.2007.06.002 


\section{Notes}

Note 1. Although unfounded, this choice of stock return as a measure of news was taken up by the majority of post-Basu studies (1997).

Note 2. Basu (1997), Pope \& Walker (1999), Ball, and al., (2000), Ball \& Shivakumar (2006), Moreira \& Pope (2006) amongst other.

Note 3. At the moment of their occurrence, there is no uncertainty about their amounts.

Note 4. Except accrual Drivers, change in revenue, for Dimitropoulos (2008).

Note 5. Although unfounded, this choice of stock return as a measure of news was taken up by the majority of post-Basu studies (1997).

Note 6. According to Basu (1997, p.11), the use of reverse regression is advantageous because Ordinary Least Squares method (OLS) and statistical tests are well specified when explained variable is used as an independent variable and explanatory variable as dependent variables. In addition, reverse regression avoids effect of microstructure, liquidity and return-rating problems when return are used as explanatory variables (Ball, and al., 2000).

Note 7. Basu (1997, p.10) : "Buy-and-hold annual returns are calculated to end three months after the fiscal year-end to ensure that the market response to the previous year's earnings is excluded: post-earnings-announcements".

Note 8. Accruals aggregate estimated using balance sheet approach (Richardson, and al., 2005).

Note 9. Preferred shares are hybrid securities with characteristics unique to both equities and fixed income securities. Similar to a holding interest, a preferred share is an equity interest, generally does not have a maturity date, and is recognized as a share in the balance sheet. However, like an obligation, a preferred share generally does not include voting rights, has a face value and, usually, a fixed rate of distribution determined at the time of issuance. Thus Richardson, and al., (2005), considering the preferred shares as debt securities (bonds) include them as debts.

Note 10. Some authors recommend adjusting returns through dividends paid. However, other such as Easton, Harris and Ohlson (1992) and Dumontier \& Labelle (1998) have shown that the use of dividends for returns adjustment does not affect the results. We chose to not consider dividends when calculating stock market returns.

Note 11. 511 French companies, whose stock and financial data are identified by the Datastream database, were selected. Financial institutions have been eliminated. Initially a study period of 20 years, from 1996 to 2015, was selected. However, by reducing the period to 16 years from 2000 to 2015, the sample size is maximised. For this period, only companies with complete data are selected. In order to maximize the size of the sample and to minimize the bias of the cylinders, companies with a maximum of two years of missing observations are reintegrated. An unbalanced panel of 331 companies is selected.

Note 12. The Shapiro-Wilk Normality Test shows that all variable doesn't follow normal law (all p-value $<1 \%$ ).

Note 13. The White (1980) heteroscedasticity test results reflect the existence of heteroscedasticity for all years of the study with the exception of 2008. The Durban-Watson order 1 autocorrelation test shows the absence of order 1 autocorrelation for the years 2000, 2005, 2006 and 2009. For the rest of the years, there is uncertainty about the existence of either a positive or a negative correlation.

Note 14. Fisher Test, Lagrange Multiplier Test and Hausman Test.

Note 15. Breush-Pagan Test (Random effect model) / Modified Wald Test (Fixed effect model).

Note 16. Fisher Test, Lagrange Multiplier Test and Hausman Test.

Note 17. Modified Wald Test.

Note 18. Wooldridge Test.

Note 19. Fisher Test, Lagrange Multiplier Test and Hausman Test.

Note 20. Modified Wald Test.

Note 21. Wooldridge Test. 